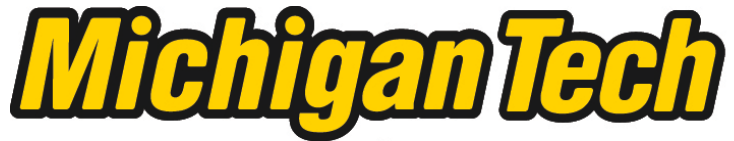 \\ Michigan Technological University Create the Future Digital Commons @ Michigan Tech
}

Dissertations, Master's Theses and Master's Reports - Open

Dissertations, Master's Theses and Master's

Reports

2011

\section{U.S. utilities' experiences with the implementation of energy efficiency programs}

Courtney Goss

Michigan Technological University

Follow this and additional works at: https://digitalcommons.mtu.edu/etds

Part of the Environmental Policy Commons

Copyright 2011 Courtney Goss

\section{Recommended Citation}

Goss, Courtney, "U.S. utilities' experiences with the implementation of energy efficiency programs", Master's Thesis, Michigan Technological University, 2011.

https://doi.org/10.37099/mtu.dc.etds/306

Follow this and additional works at: https://digitalcommons.mtu.edu/etds

Part of the Environmental Policy Commons 


\title{
U.S. UTILITIES' EXPERIENCES WITH THE IMPLEMENTATION OF ENERGY EFFICIENCY PROGRAMS
}

\author{
By \\ Courtney Goss
}

\begin{abstract}
A THESIS
Submitted in partial fulfillment of the requirements for the degree of

MASTER OF SCIENCE

Environmental Policy
\end{abstract}

MICHIGAN TECHNOLOGICAL UNIVERSITY

2011

(C) 2011 Courtney Goss 
This thesis, "U.S. utilities' experiences with the implementation of energy efficiency programs," is hereby approved in partial fulfillment of the requirements for the Degree of MASTER OF SCIENCE IN ENVIRONMENTAL POLICY.

Department of Social Sciences

Signatures:

Thesis Advisor

Dr. Barry Solomon

Department Chair

Dr. Patrick Martin

Date 


\section{Table of Contents}

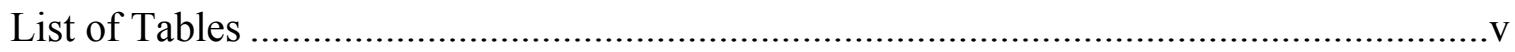

List of Abbreviations ……………...................................................................... vi

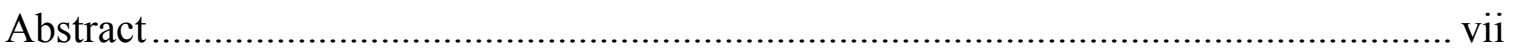

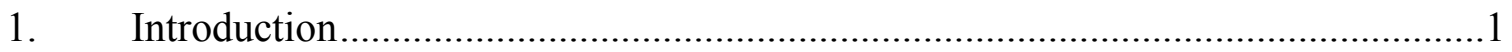

2. U.S. Electric Utility System \& Energy Policies ……..........................................

$2.1 \quad$ U.S. Electric Utility System..............................................................6

2.2. U.S. Federal Energy Policies ...............................................................

2.3. Impacts of U.S. Electric Industry Restructuring .......................................12

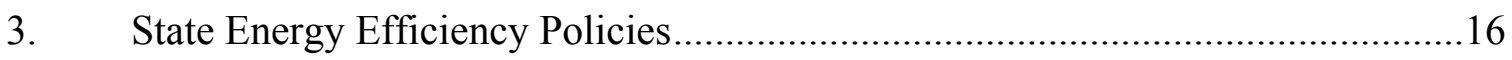

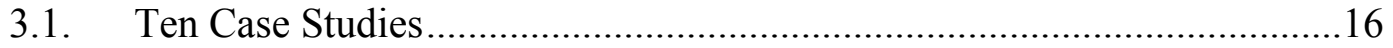

3.1.1. Connecticut ............................................................................16

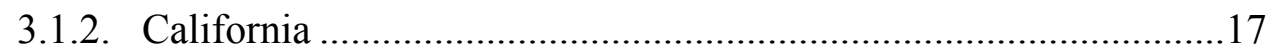

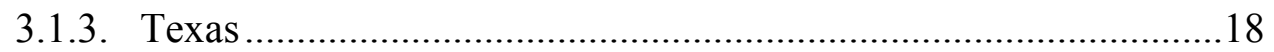

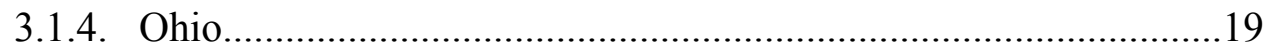

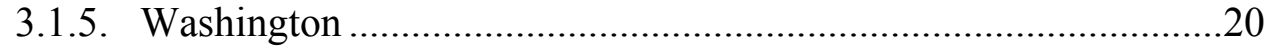

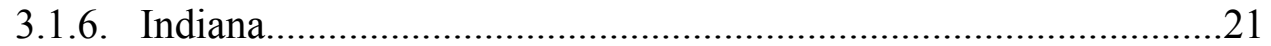

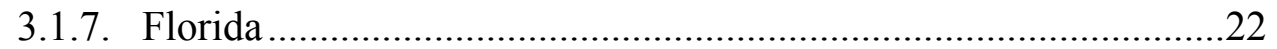

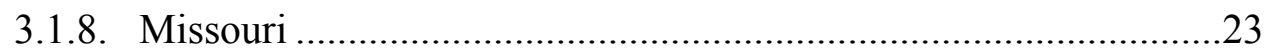

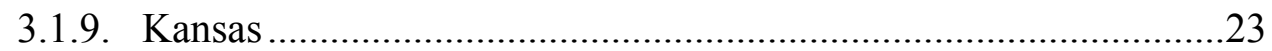

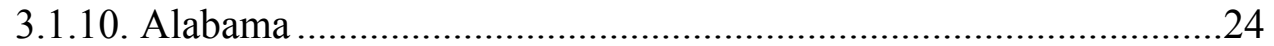

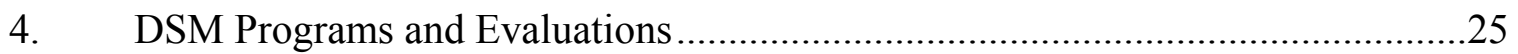

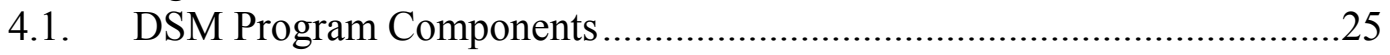

4.2. DSM Program Evaluation..................................................................28

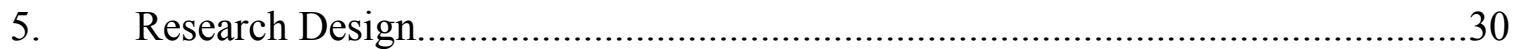

5.1. Choosing Utilities for Case Studies .........................................................

5.2. Evaluation Criteria and Data for Case Studies ............................................34

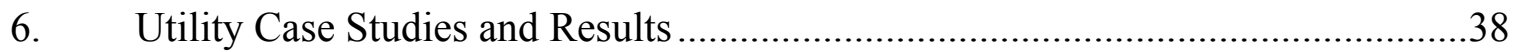

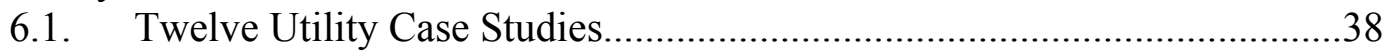

6.1.1. Pacific Gas and Electric ...............................................................38

6.1.2. City of Palo Alto Utilities ...................................................................

6.1.3. Connecticut Light and Power.......................................................41

6.1.4. Austin Energy …………………………………....................42

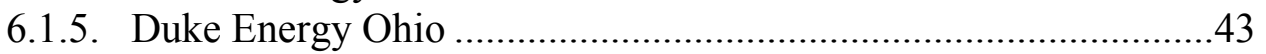

6.1.6. Seattle City Light ............................................................................4 


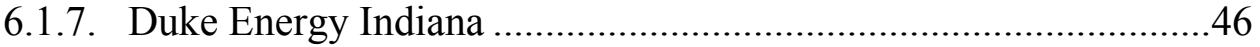

6.1.8. Florida Power and Light .....................................................4 47

6.1.9. Kansas City Power and Light Missouri ........................................48

6.1.10. Kansas City Power and Light Kansas ........................................49

6.1.11. Kansas City Board of Public Utilities .......................................50

6.1.12. Alabama Power....................................................................51

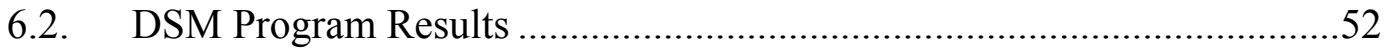

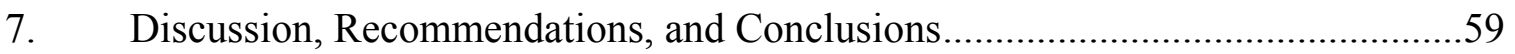

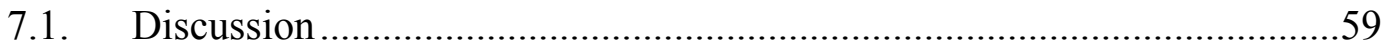

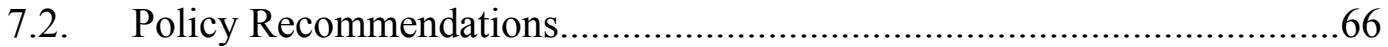

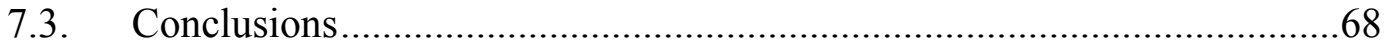

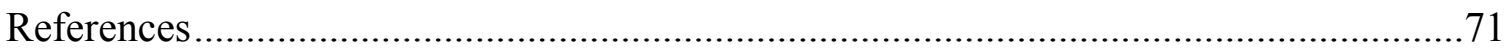




\section{List of Tables}

Table $3.1 \quad$ State energy efficiency policies …………….......................................24

Table $5.1 \quad$ Utility companies in the case studies.........................................................

Table 6.1 Residential sector 2009 annual energy effects from DSM programs ............53

Table 6.2 Commercial sector 2009 annual energy effects from DSM programs ..........53

Table 6.3 Industrial sector 2009 annual energy effects from DSM programs...............54

Table 6.42009 annual peak demand reductions by sector (MW) ...............................55

Table 6.5 2009 total utility cost (\$) of energy efficiency programs per customer ............................................................................................56

Table 6.6 2009 total utility cost (\$) of energy efficiency programs per kWh saved by the utility. 


\section{List of Abbreviations}

ACEEE. American Council for an Energy-Efficient Economy

CFL. Compact fluorescent light bulb

CL\&P. Connecticut Light \& Power Company

CO $\quad$ Carbon dioxide

CPAU. City of Palo Alto Utility

CPUC. California Public Utilities Commission

DOE. U.S. Department of Energy

DPUC. Connecticut Department of Public Utility Control

DSM. Demand-side management programs

ECMB. Connecticut Energy Conservation Management Board

EECRF. Texas Energy Efficiency Cost Recovery Factor

EIA. U.S. Energy Information Administration

EPAct. Energy Policy Act of 1992

FEECA. Florida Energy Efficiency and Conservation Act

FERC. Federal Energy Regulatory Commission

FP\&L. Florida Power \& Light

FPSC. Florida Public Service Commission

GWh. Gigawatt-hour

HES. Home Energy Solutions

HVAC. Heating, ventilating, and air conditioning

IRP. Integrated resource planning 
IURC. Indiana Utility Regulatory Commission

KCBPU. Kansas City Board of Public Utilities

KCC. Kansas Corporation Commission

KCP\&L. Kansas City Power and Light

kWh. Kilowatt-hour

MW. Megawatt

MWh. Megawatt-hour

NECPA. National Energy Conservation Policy Act

NWPCC. Northwest Power and Conservation Council

PGC. Public Goods Charge

PG\&E. Pacific Gas and Electric

PUCT. The Public Utility Commission of Texas

PURPA. Public Utilities Regulatory Policies Act of 1978

RTO. Regional Transmission Organization

SBC. System benefit charge 


\begin{abstract}
In the U.S., many electric utility companies are offering demand-side management (DSM) programs to their customers as ways to save money and energy. However, it is challenging to compare these programs between utility companies throughout the U.S. because of the variability of state energy policies. For example, some states in the U.S. have deregulated electricity markets and others do not. In addition, utility companies within a state differ depending on ownership and size. This study examines 12 utilities' experiences with DSM programs and compares the programs' annual energy savings results that the selected utilities reported to the Energy Information Administration (EIA). The 2009 EIA data suggests that DSM program effectiveness is not significantly affected by electricity market deregulation or utility ownership. However, DSM programs seem to generally be more effective when administered by utilities located in states with energy savings requirements and DSM program mandates.
\end{abstract}




\section{Chapter 1: Introduction}

With a growing population and increasing carbon emissions in the United States, energy is quickly becoming one of the top environmental issues in the country. Energy production and use is one of the leading causes of climate change. The United States emits more carbon dioxide $\left(\mathrm{CO}_{2}\right)$ per capita than any other industrialized country, so it is essential that the United States decreases carbon emissions to fight global climate change (Byrne et al. 2007). For decades now, there has also been speculation that the availability of petroleum supplies in the long-term will be problematic (Heinberg 2003). With a heavy dependence on fossil fuels, the United States should look to renewable energy sources and energy efficiency to alleviate the pressure on the supply of non-renewable resources.

Not only is energy efficiency a key to combating climate change and energy shortages, but it is also an important economic factor for the future of energy because it gives the consumer a way to battle rising energy costs. The increasing cost of energy is a growing problem in the United States; the U.S. Energy Information Administration predicted that average electricity costs will continue to rise in the future (Tonn and Peretz 2007). In order to save money, people can either conserve energy or invest in costeffective energy efficiency technologies. To achieve energy efficiency, equipment for lighting, heating, cooling, or other energy services should be replaced or maintained to get the same service with less energy use. Efficiency is measured by the quantity of output divided by the quantity of energy input. Efficient technologies have a higher upfront cost, but the customer will eventually save money and energy. In contrast, 
energy conservation refers to reducing the amount of energy consumed, often with a change in behavior. By using energy more efficiently and conserving energy, consumers and utilities can save money, shareholders can increase profits through avoided capital investments, and negative environmental impacts can be minimized (U.S. Congress, Office of Technology Assessment 1993).

One way for the United States to increase energy savings is through utility efficiency programs. Electric utility companies are very important to the United States as they provide homes, businesses, and industries with electricity. As one of the largest energy users in the United States, utility companies are leading purchasers of primary energy sources such as coal, gas, uranium, and oil (U.S. Congress, Office of Technology Assessment 1993). Utilities could use energy efficiency as a resource to decrease the number of new expensive power plants that need to be built and lessen the amount of primary energy sources that are required to meet electricity demand (Geller 2004). Since electricity use is growing, some utilities plan to use energy efficiency as a resource to meet $20-40 \%$ of their potential load growth (Berry 2008). It was also predicted by the Energy Efficiency Task Force that the western United States could decrease its energy use by $20 \%$ from projected levels to 2020 through the use of "best-use energy efficiency programs" (Berry 2008).

In 2008, 38 states in the U.S. had some form of energy efficiency programs (M.J. Bradley \& Associates 2009). The commitment level and investments vary from state to state, along with the type of energy efficiency programs that are implemented. For example, utilities could provide incentives to customers to purchase efficient appliances 
or implement educational programs to inform customers of wise energy use (Tonn and Peretz 2007). These are examples of demand-side management (DSM) programs, which are typically cost effective for utilities. Baker-Stariha (1993) defined DSM as including "any activity undertaken by a supplier to alter demand in order to reduce the suppliers' costs." Though this is a broad definition, DSM typically applies to load management and energy efficiency (Curtis and Khare 2004). A successful DSM program can cost around $\$ 0.02-\$ 0.03$ per $\mathrm{kWh}$, which is lower than the cost of generating one $\mathrm{kWh}$ of electricity. This is why energy efficiency is used as a technique to meet load growth. Utilities receive benefits from reduced electricity demand, such as cost savings with reduced fuel use, fewer capital investments, and a potential shift away from energy use during peak hours. Though costs to utilities could eventually be lessened with DSM programs, there will still be a loss of revenue to utilities through reduced electricity use, especially from the residential sector. However, this isn't necessarily a cost attributed solely to DSM programs because customers could potentially reduce their own electricity use without any influence from utility programs (Curtis and Khare 2004). DSM programs are typically funded with a small percentage of total revenue from customers (around 2-3\% in "successful" programs), and may also receive funding from the state or federal government (Geller 2004).

DSM funding sharply declined in the late 1990s with the restructuring of the U.S. electricity industry. In 1996, the Federal Energy Regulatory Commission (FERC) introduced Order 888, which called for open access to electricity transmission lines (Sioshansi 2001). The purpose of restructuring the electricity industry was to increase 
competition so that electricity prices could be driven lower and monopolies could be broken. However, the restructuring effort in the United States has been deemed by some to be a "failure," though there was moderate success in Pennsylvania and New Jersey (Sioshansi 2001). It has also been suggested that deregulation of the electricity market harmed the progress of energy efficiency programs. Without regulation and funding, there would be little incentive for utilities to continue to invest in DSM programs (Palmer and Burtraw 2005). Others speculated that private energy service companies may help large electricity consumers save electricity, turning DSM programs into a "private enterprise."

DSM programs are an important approach to lower $\mathrm{CO}_{2}$ emissions and decrease overall energy use in the U.S. The success of these programs could have a great impact on reducing the amount of fossil fuels that are used for electricity generation. This thesis will focus on DSM programs and will review the implementation process of these programs for various utility companies throughout the U.S. In Chapter 2, background information will be provided on the structure of the U.S. electric utility system, and federal and state policies that affect the electricity industry. Similarly, Chapter 3 will include background information on state energy efficiency policies for ten states chosen for case studies. These selected states demonstrate the wide variety of energy policies in the U.S. Next, Chapter 4 will provide background information on the components of utilities' DSM programs and how these programs are evaluated.

In Chapter 5, the research design for this thesis will be explained. The programs chosen for this study were selected from states that have deregulated their electricity 
markets and those that have not. It is important to look at both types of electricity markets because some states may place more of an emphasis on DSM programs than others. In addition, the selected utility companies represent utilities that are both investor-owned and public because there may be detectable differences between DSM programs for both types of utilities.

Next, Chapter 6 will report the main findings of this research. Within this chapter, there will be case studies discussing the background and current status of 12 utilities' energy efficiency programs. Also, there will be data presented on the annual energy savings from utility DSM programs in 2009 and other various criteria that utilities reported to the Energy Information Administration.

In Chapter 7 of this thesis, the DSM program results will be explained and comparisons between utilities will be developed. Also, state energy efficiency policies will be examined in the context of the chosen utilities and their DSM programs, and any correlation between policies and energy savings will be discussed. Finally, this thesis will suggest possible reasons for success and struggles of DSM programs in the U.S. and will conclude with recommendations for future state energy policies. 


\section{Chapter 2: U.S. Electric Utility System \& Energy Policies}

\section{U.S. Electric Utility System}

In the U.S., there are different types of electric utility companies, including investor-owned utilities, public electric power systems, and rural electric cooperatives (U.S. Congress, Office of Technology Assessment 1993). The ownership of utilities is important because it dictates whether companies are regulated by the government and affects the administration of energy efficiency programs (Blumstein et al. 2005).

Investor-owned utilities are private companies that are owned by shareholders. The rates that these utilities charge are regulated by state public utility commissions. Investor-owned utilities operate to maximize their profits, and therefore typically focus on earnings in the short run. In contrast, public power utilities are typically owned by municipalities and are regulated by an elected board or city council (with the exception of Nebraska, which established the Nebraska Power Review Board in 1963). Since public utilities are supposed to benefit the public, they are non-profit and have more of a longterm perspective. Therefore, public utilities usually are not subject to state regulations like investor-owned utilities. However, though state public utility commissions typically do not regulate public utilities' rates, some commissions mandate public utilities to pursue energy efficiency options (American Public Power Association 2011). The third type of utility company is rural electric cooperatives, which are owned by members and regulated by an elected board of directors. These cooperatives were formed after Congress created the Rural Electrification Administration in 1935, which extended electricity to rural areas of the U.S (U.S. Congress, Office of Technology Assessment 
1993). Like public utility companies, rural electric cooperatives are typically not regulated directly by the state governments.

\section{U.S. Federal Energy Policies}

The energy sector has played a vital role in the development of the United States' economy. During the 1800s, energy was one of the keys to industrialization and expansion of the U.S. economy. As the economy grew throughout the $20^{\text {th }}$ century, so did the demand for electricity. The amount of electricity consumed in the U.S. increased by 7 percent per decade in the 1960s and 1970s. Electricity consumption slowed in the 1990s to 2.1 percent, but it continues to grow today (Sharabaroff et al. 2009). As electricity use expanded, so did the largest electricity generators. Since these electricity generators had a large customer base, some of their capital costs were diluted and they were able to generate electricity at a lower cost than smaller electricity generators, which were then rendered uncompetitive. The growth of electricity demand and these large electricity generators led to natural monopolies in the electricity sector.

One of the first important pieces of federal legislation that moved the electricity industry towards restructuring and energy efficiency was the Public Utilities Regulatory Policies Act of 1978 (PURPA). According to the FERC, this Act was passed to "promote energy conservation and alternative energy technologies and to reduce oil and gas consumption through use of improved alternative energy technologies and regulatory reforms" (Federal Energy Regulatory Commission 2006). PURPA required utilities to purchase electricity from small-scale production facilities (Menz 2005). By encouraging 
the introduction of additional energy producers into the electricity market, PURPA was one of the first steps towards restructuring the industry and moving away from monopolies through the introduction of competition (Sharabaroff et al. 2009). PURPA was also important because it was one of the first laws to acknowledge the need for energy conservation and improved energy technologies.

Another key law passed the same year was the National Energy Conservation Policy Act (NECPA), which has provided a foundation for U.S. energy policy. The NECPA has been amended since its creation, but initially encouraged residential consumers to conduct electricity audits and decrease their demand for electricity (U.S. Department of Energy 2009). These provisions of the NECPA provide a foundation for DSM programs.

Another piece of federal legislation that encouraged energy efficiency was the National Appliance Energy Conservation Act of 1987. This Act was important because it established minimum efficiency standards for common appliances such as: refrigerators, freezers, room air-conditioners, clothing washers and dryers, and water heaters. By establishing appliance efficiency standards, residential consumers could conserve energy by purchasing and using new efficient products. In 1987, Congress established these standards with the knowledge that the U.S. Department of Energy (DOE) would perform scheduled reviews of these standards and adjust them as needed (United States Department of Energy 2008).

The next major piece of federal legislation to impact the electricity industry was the Energy Policy Act of 1992 (EPAct), which amended NECPA. The EPAct also 
encouraged energy efficiency and additional wholesale competition in the electricity industry (U.S. Department of Energy 2009). One of the provisions of the EPAct recommended that government agencies enter into negotiations with electric utilities to design cost-effective DSM programs that would address the needs of the agencies' facilities. The agencies were able to collect any incentives or rebates just as any other customers in the program would.

The EPAct also had provisions that moved the electricity market towards competition and away from monopolies. For example, it states that the rates utility companies charge should not place smaller companies or utilities engaging in DSM activities at a disadvantage (U.S. Department of Energy 2009). Integrated resource planning (IRP), which is a technique for regulatory commissions and utilities to assure that reliable and economic electricity is available for the public, was also encouraged. IRP is also referred to as least-cost planning, as utilities are to consider demand and supply-side options and develop a plan to meet current and future electricity needs at the lowest cost possible, instead of merely constructing additional power plants (U.S. Congress, Office of Technology Assessment 1993). IRP is a technique that is still used by many utilities and often includes DSM programs as a low cost option to meet electricity demand. Least-cost planning has led to a conceptual shift that demand-side options are low cost for the utility (Eto 1996).

By 1996, the transition to restructuring the electricity industry was underway with Order 888 from the FERC. Order 888 's purpose was to introduce the concept of opening access to transmission lines (Sioshansi 2001). This was intended to create wholesale 
competition in the electricity market and increase the chance of smaller electricity generators getting their power to customers. In 1996, the FERC also released Order 889, which required the development of an electronic bulletin board known as the Open Access Same-Time Information System (Sharabaroff et al. 2009). This system was used to share information about electricity transmission availability and its cost with potential customers (Palmer and Burtraw 2005). Next, the FERC built upon Order 888 with Order 2000, which encouraged utilities to join a Regional Transmission Organization (RTO). RTOs are defined as "independent entities that operate the transmission grid and seek to prevent discrimination by the transmission owner against competing electricity generators" (Palmer and Burtraw 2005). Every RTO, with the exception of one in Texas, is in the FERC's jurisdiction and is subject to its oversight.

Numerous states have deregulated as an attempt to lower the cost of electricity and offer customers a choice of alternative power suppliers. However, despite the FERC's efforts in the late 1990s to increase competition for wholesale electricity and participation in RTOs, deregulation has not been accepted by all states. With opposition from some politicians and special interest groups, the FERC's goal to have a seamless national electric power market has not yet been achieved. There are states that have resisted restructuring because they have no reason to change their electricity market, and others fear that it could have a negative effect on electricity prices and reliability (Sioshansi 2001). Some states were wary of deregulation because it would lead to utilities having sunken investments that were once backed by regulators before discussion of a state policy change (Palmer and Burtraw 2005). 
In 1998, California and Massachusetts opened their electricity markets and were shortly followed by Pennsylvania, New York, New Jersey, and Texas (Sioshansi 2001). The success of restructuring varied between these states. Though restructuring was supposed to lead to more competition and lower electricity prices, results have been mixed as the price margins have not always been high enough between utilities to have customers in open-market states switch their service provider (Sioshansi 2001). Pennsylvania is often deemed a success, as $12.5 \%$ of the customer base switched electricity suppliers within the competitive market in 2001 (Sioshansi 2001). However, there has been a decline in customer participation in recent years. It is still considered a success in comparison to other states that have deregulated their markets. Ohio is the most successful after Pennsylvania with 5.3\% of the customer base switching suppliers in the competitive market (Sioshansi 2001). New York, New Jersey, and Massachusetts have also had more modest results than Pennsylvania and Ohio, so it is difficult to claim that deregulation has been successful.

California is often referenced as an example of open-market failure, as it declared an end to its open-market in September 2001 (Palmer and Burtraw 2005). In California, there was a market crash during the summer of 2001 because the demand for electricity was greater than the available supply in the deregulated market, among other factors (Vine et al. 2006; Brennan et al., 2002). Due to the market failure, there were blackouts and major rate increases (Sioshansi 2001). After the electricity market crash, the California Public Utilities Commission decided to suspend open access to the market, and customers were no longer allowed to switch electricity suppliers (Vine et al. 2006). One 
other outcome of the failed market was a new set of policy initiatives. In 2001, California policymakers and utility regulators greatly increased the funding for energy efficiency programs. The energy crisis influenced California's policies so greatly that its energy efficiency funding was equal to the funding of all energy efficiency programs in every other state combined (Vine et al. 2006).

With the failure of California's open-market, other states have been apprehensive about deregulating their electricity market. Currently, there are 15 states with deregulated markets, including: Oregon, Texas, Illinois, Michigan, Ohio, Pennsylvania, Maryland, Delaware, New Jersey, New York, Connecticut, Rhode Island, Massachusetts, New Hampshire, and Maine (U.S. Energy Information Administration 2010b). Several other states currently have suspended deregulated markets, including: California, Nevada, Arizona, New Mexico, Montana, Arkansas, and Virginia. Recognizing which states have deregulated electricity markets will help identify what effects deregulation has on the experiences of utility efficiency programs in those states.

\section{Impacts of Electric Industry Restructuring}

Looking back at the effects of restructuring, it can be observed that investorowned utilities' investments in energy efficiency programs dropped substantially during the early stages of the process (Palmer and Burtraw 2005). Many utilities abandoned these programs in order to lower prices and be competitive in the market. Between 1993 and 1999, investment in DSM programs fell by 55\%, and "incremental annual energy savings" dropped by 65\% (Palmer and Burtraw 2005). However, by 1999 investments in 
energy efficiency programs increased in states that started public benefit funds. These funds were often controlled by state agencies, which administered energy efficiency programs instead of utilities (Blumstein et al. 2005). Energy efficiency programs in the U.S. are now administered by state agencies, utility companies, and non-profits, depending on state policies and utility ownership.

Deregulation had different effects on utility companies based on the ownership of the utility and the state in which it is located. For example, it became more common for investor-owned companies to abandon DSM programs to lower their prices and increase their appeal in the competitive market of deregulated states. In order to promote energy efficiency and renewable energy programs, some state governments now require investor-owned companies to collect system benefit charges (SBC), or a public benefit fund. These fees are typically collected as an additional charge on customers' bills and are applied to benefit the public through low-income energy assistance, renewable energy investments, or DSM programs (Database of State Incentives for Renewables and Efficiency 2010b). For example, in 1996, New York implemented a system benefits charge that required investor-owned utilities to collect a certain percentage of their revenue ( $1.42 \%$ in 2004) from a surcharge on customers' bills. This is a common policy that some states implement to ensure that investor-owned utilities continue to invest in beneficial programs for the public.

In addition to investor-owned utilities, public utilities also often offer DSM programs and services to their customers. Many of these energy efficiency programs are funded by ratepayers, though utilities can also receive funding from state government 
agencies or the federal government for specific programs (Blumstein et al. 2005). One example of a federally funded efficiency program is the low-income weatherization assistance program that is offered in each state, which began under the NECPA of 1978 (U.S. Department of Energy 2010). During restructuring, there was less concern regarding public utilities abandoning energy efficiency programs because they are held accountable by their customers and do not operate for profit (Oregon People's Utility District Association 2010). Theoretically, if customers want to reduce their energy use through efficiency programs, public utilities should provide that option. Though public utilities are likely to offer energy efficiency programs without mandates, there are some public utility commissions that require public utilities to pursue energy efficiency and meet savings targets.

Through restructuring, people were supposed to be able to choose their energy provider among various investor-owned and public utilities. However, that option does not exist in all states. Since individual states made the decision to deregulate, the U.S. electric utility system is lacking federal policies to create a uniform nationwide market. Energy efficiency programs vary between states based on the state policies, level of regulation, utility ownership, and the programs' administrators (Blumstein et al. 2005). Deregulation provided an incentive for investor-owned utilities to abandon efficiency programs to avoid a surcharge for ratepayers and to remain competitive. Public utilities would not have this incentive because they do not operate for profit. However, if a deregulated state has policies in place that require DSM programs, investor-owned utilities would need to comply with these policies. 
By evaluating the implementation experiences of individual utilities and their DSM programs, the influence that various state policies have on these programs' effectiveness should be evident. To assess this influence, ten case studies of state energy efficiency policies will be developed to demonstrate any relation between state policies and utility DSM program results. 


\section{Chapter 3: State Energy Efficiency Policies}

\section{Ten Case Studies}

In the U.S., state energy efficiency policies vary greatly; there are states that mandate energy efficiency programs, others that set annual energy savings goals, and states that do all or none of the above. To demonstrate the differences in state energy efficiency policies, ten states were chosen that vary based on efficiency mandates, annual savings goals, and program funding. The ten selected states represent all levels of the spectrum in the U.S., from states that have historically invested in energy efficiency to those that still invest very little. Later in this thesis, utilities located in these states and their energy efficiency programs will be evaluated to observe any possible correlation between state policies and program results.

\section{Connecticut}

Connecticut requires both investor-owned and municipal electric utilities within the state to offer conservation and load management programs. In 1998, Connecticut passed its electric industry restructuring legislation, which established the Energy Conservation Management Board (ECMB). The ECMB is appointed by the Department of Public Utility Control (DPUC), and works with investor-owned utilities to develop their energy efficiency programs. The goals for these efficiency programs are set by the utilities during hearings with the ECMB, and have to be approved by the DPUC. In addition, the ECMB is required to submit annual assessments to the Connecticut 
legislature that address the costs and benefits of efficiency programs from the previous year (American Council for an Energy-Efficient Economy 2010).

To fund energy efficiency programs, the Connecticut legislature has mandated a SBC. Investor-owned utility DSM programs are funded by a SBC on consumers' bills that amounts to approximately 0.3 cents per kWh (CT Energy Info Center 2011). Since 2006, municipal utilities in Connecticut were mandated to support energy efficiency programs with a SBC of 0.1 cents per $\mathrm{kWh}$.

Additional important energy efficiency legislation was implemented in Connecticut with the passage of the 2007 Electric and Energy Efficiency Act. This Act required electric utility companies to submit IRPs and consider all possible supply and demand options. With this Act, distribution companies are also supposed to eliminate electric demand growth and pursue every cost-effective energy efficiency option (State of Connecticut 2007). However, this may prove difficult to achieve as the DPUC recently did not approve an increase in the funding for energy efficiency programs that would be necessary to satisfy the legislation's requirements.

\section{California}

Since the 1970s, California has been a leader in utility energy efficiency programs. California's efficiency programs are credited for decreasing the per capita energy use within the State. The California Public Utilities Commission (CPUC) sets goals and approves spending levels for mandated investor-owned utility energy efficiency programs. Municipal utilities in California also must offer efficiency programs, though 
they set their own savings targets and spending levels. In addition, municipal utilities in California must report annual DSM cost-effectiveness to their customers (American Public Power Association 2011).

The amount of energy efficiency funding greatly increased in California after the 2001 electricity crisis and suspension of the deregulated market (Vine et al. 2006). Currently, energy efficiency programs in California are funded with a SBC called the Public Goods Charge (PGC). The surcharge is about 0.48 cents per kWh with 0.3 cents per kWh being used for energy efficiency programs, and the remainder is applied to renewable energy research and development (Adi Kuduk and Anders 2006).

In 2001, energy savings goals were also developed for investor-owned utilities by state agencies and utilities. The goals were finalized by the CPUC in 2004 and called for energy reductions of 23 billion kWh for efficiency programs between 2004 and 2009. In addition, efficiency programs were mandated to decrease peak demand by 4.9 million $\mathrm{kW}$ during the same timeframe. In 2008, the CPUC extended energy savings goals for investor-utilities from 2012 to 2020. During this time period, the new savings targets are expected to save an additional 16 billion kWh of electricity and decrease peak demand by an extra 4.5 million $\mathrm{kW}$ in California (American Council for an Energy-Efficient Economy 2010). The extension of ambitious energy efficiency goals demonstrates California's dedication to these programs and the concept of energy efficiency.

Texas 
In 1999, Texas became the first state to implement an energy efficiency resource standard, which requires all electric transmission and distribution utilities to offset 20 percent of their load growth through energy efficiency. This goal started as only 10 percent but has increased through the years; there is currently discussion of whether a goal of 50 percent of load growth by 2015 is feasible (Public Utility Commission of Texas 2010). Texas has incentives in place for utilities to meet their energy savings goals. If a utility company surpasses their goal, they can receive an award of one percent of the net benefits for every two percent that they exceed their goal.

In order to meet these goals, utilities administer energy efficiency programs. In Texas, utility companies are permitted to recover the costs of efficiency programs through a rate schedule called the Energy Efficiency Cost Recovery Factor (EECRF). The Public Utility Commission of Texas (PUCT) must approve utility base rates, which can include a small amount to fund efficiency programs or they can approve a monthly charge on bills for the EECRF (American Council for an Energy-Efficient Economy 2010). In addition, public utilities in Texas which sell more than 500,000 megawatt-hours of electricity are required to offer energy efficiency programs (American Public Power Association 2011).

\section{Ohio}

In Ohio, all investor-owned utilities are required to implement energy efficiency programs. Annual and long-term plans must be submitted to the Public Utilities Commission of Ohio. In 2009, energy savings standards were mandated in Ohio; utilities 
were required to save 0.3 percent of the average $\mathrm{kWh}$ sales from the previous three years. Distribution utilities were also supposed to decrease peak demand by one percent in 2009 , and peak demand reductions should be equal to seven percent of the average electricity sales of the previous three years by 2017 (Database of State Incentives for Renewables and Efficiency 2010a). All of these energy savings goals will increase in the future. Utilities that do not meet their goals are penalized with a fine equal to the current market value of one renewable energy credit per MWh of the remaining energy savings goal that was not met. These fines are then directed to an Advanced Energy Fund. Funding for energy efficiency programs comes from the Advanced Energy Fund, which is administered by the Ohio Energy Resources Division. The funding is accumulated from a rider of nine cents every billing period for each customer from all of

Ohio's investor-owned utilities. In addition, there is a statewide surcharge of $\$ 0.0001758$ per kWh that is applied to Ohio Energy Loan Fund, which provides low income consumers with bill assistance and energy efficiency incentives (Ohio Department of Development 2007).

\section{Washington}

Historically, Washington has included energy efficiency as a resource for energy planning and investment decisions. In 2006, voters in Washington approved ballot initiative 937, which created new requirements for energy conservation. Since the initiative was implemented in 2007, all Washington utilities with at least 25,000 customers are required to pursue all cost-effective energy conservation efforts. This 
applies to both public and private utilities. Utilities are supposed to calculate what their cost-effective conservation potential is through 2019, and set biennial energy savings targets to reach their 2019 goals (State of Washington 2006). In addition, the methodologies that utilities use to calculate their cost-effective conservation potential must be consistent with methods used by the Northwest Power and Conservation Council (NWPCC) in its 2010 Sixth Northwest Power Plan. The NWPCC is a four-state regional energy planning council, which is working on developing a 20 year electric power plan that will have the lowest possible economic and environmental costs and will deliver reliable power to the Northwest (Northwest Power and Conservation Council 2010).

Currently, Washington does not have a SBC to support energy efficiency programs. Investor-owned utilities in Washington add a tariff rider onto customer bills to recover the programs' costs. Public utilities in Washington also provide DSM programs and are well-known for their commitment to energy efficiency. These programs are supported by the utilities and a small cost to customers (American Council for an EnergyEfficient Economy 2010).

\section{Indiana}

In July 2010, the Indiana Utility Regulatory Commission (IURC) ordered investor-owned utilities in the State to submit three year DSM plans with expected incremental progress on how they will meet their energy savings goals. The goals start at 0.3 percent in 2010 and will slowly increase until reaching two percent annual savings in 2019 (Indiana Utility Regulatory Commission 2010a). To achieve these savings, Indiana 
utilities are to provide standard core DSM programs such as a residential lighting program, home audits, and low-income weatherization. Evaluations of the DSM programs will be performed by a third-party and will be calculated as total energy reduction. If a utility does not achieve their goals, they must meet with the IURC and discuss with them how they plan to improve their DSM programs.

Energy efficiency programs in Indiana have historically been small with minimal effects, but these new mandates in 2010 are intended to make energy efficiency a more important energy resource for utilities. DSM programs in Indiana are typically funded with a tariff on customers' bills (Indiana Utility Regulatory Commission 2010a).

\section{Florida}

Electric utilities in Florida that sell over 2,000 GWh per year are required to adhere to the 1980 Florida Energy Efficiency and Conservation Act (FEECA), which requires utilities to implement cost-effective efficiency programs. Florida utilities use DSM programs to satisfy FEECA requirements and they can create their own program goals, which are approved by the Florida Public Service Commission (FPSC). In addition, utilities must submit annual reports to the FPSC and update DSM program goals at least once every five years with FPSC approval (Florida Public Service Commission 2006). Though utilities decide their individual program goals, in 2009 the Florida Public Utilities Commission set an energy savings goal of 3.5 percent to be met by each utility within ten years. 
The funding for DSM programs in Florida can be collected from a flat tariff set by the utility that appears on customers' bills. Another program funding option in Florida is the Energy Conservation Cost Recovery factor, which is an amount per kWh applied to customers' bills (American Council for an Energy-Efficient Economy 2010).

\section{Missouri}

Missouri recently passed legislation that will dramatically increase the funding and options for energy efficiency programs within the State. The Missouri Energy Efficiency Investment Act of 2009 requires investor-owned utilities to seek out all costeffective energy efficiency opportunities. DSM programs are now to be considered equally to other traditional energy resources. Though there have been IRPs and DSM programs in Missouri since the early 1990s, they were ineffective and had low utility investment levels until recently. The 2009 legislation calls for Missouri utilities to seek "timely cost-recovery" to fund efficiency programs (Missouri Public Service Commission 2009).

Kansas

Kansas has no laws or regulations that mandate utilities to implement energy efficiency programs. In 2007, the Kansas Corporation Commission (KCC) investigated the costs and benefits of energy efficiency programs. The investigation resulted in a recommendation to develop a uniform framework for energy efficiency program encouragement and evaluation within the State. However, in 2008 the KCC decided 
against requiring energy efficiency programs. Instead, the KCC stated that it would work with utilities pursuing efficiency programs, and would consider proposals from these utilities for cost-recovery (American Council for an Energy-Efficient Economy 2010).

\section{Alabama}

In comparison to other states, spending on utility energy efficiency programs is considerably lower in Alabama; however, program spending has increased since 2008. The spending increase was not due to any regulations, as utilities in Alabama are not required to implement energy efficiency programs. There seem to be no regulatory incentives in place for utilities to pursue these programs (Institute for Energy Research 2010). Table 3.1 below summarizes the information presented in this chapter.

Table 3.1

State energy efficiency policies

\begin{tabular}{|c|c|c|c|c|}
\hline State & $\begin{array}{c}\text { Deregulated } \\
\text { Electricity } \\
\text { Market }\end{array}$ & $\begin{array}{c}\text { Program } \\
\text { Mandates }\end{array}$ & $\begin{array}{c}\text { Energy Savings } \\
\text { Targets }\end{array}$ & $\begin{array}{c}\text { Program } \\
\text { Funding }\end{array}$ \\
\hline CT & Yes & Yes & Yes & SBC .3c/kWh \\
\hline CA & Suspended & Yes & Yes & SBC .48c/kWh \\
\hline TX & Yes & Yes & Yes & Monthly Charge \\
\hline OH & Yes & Yes & Yes & Tariff-rider \\
\hline WA & No & $\begin{array}{c}>25,000 \\
\text { customers }\end{array}$ & Utilities set own & Tariff-rider \\
\hline IN & No & Yes & Yes (in 2010) & Tariff-rider \\
\hline FL & No & $>2,000$ & Utilities set own & Tariff-rider \\
\hline MO & No & Use IRP & No & Cost-recovery \\
\hline KS & No & No & No & Cost-recovery \\
\hline AL & No & No & No & Not specified \\
\hline
\end{tabular}




\section{Chapter 4: DSM Programs and Evaluations}

\section{DSM Program Components}

Demand-side management refers to utilities attempting to alter the energy use patterns of their consumers. There are different categories of DSM programs that are offered by U.S. electric utility companies, which include: education efforts to increase consumer awareness, specific recommendations for homes (typically in the form of energy audits), financial assistance and loans, free installation of energy efficient technologies, load-management (meaning that utilities provide financial incentives to customers for allowing the utility to control when they can use certain appliances), and tariffs related to the time of electricity use (Eto 1996). These last two categories are used by utility companies to shift their load or to reduce peak demand, and the other types of DSM programs are used to promote energy efficiency.

Most U.S. electric utility companies provide some sort of efficiency education to their consumers. If there is not a specific educational program, there is typically educational information on the utility's website or found with mail-inserts in customers' bills (Eto 1996). It is also becoming common for utility websites to have an online calculator that allows consumers to determine energy savings for specific product improvements such as refrigerators, air-conditioners, and lighting. Voluntary questionnaires regarding consumer energy use are also becoming common on utility companies' websites. After the consumer answers questions regarding their energy use, there is instructional information provided on how they can specifically make their home more energy efficient. 
Many utilities are now offering on-site technical advice at the consumer's request, typically as an energy audit. A utility staff consultant will conduct a walk-through of the home or commercial building and educate the consumer on efficiency improvements and cost-savings opportunities (Austin Energy, 2010). Though these energy audits are usually provided by utilities free of charge, some utilities are experimenting with charging consumers a fee for the energy audits (Eto 1996).

The most popular kinds of DSM programs in the U.S. offer financial assistance to consumers. A common type of financial assistance program is one that offers rebates to consumers for purchasing energy efficient appliances, which makes the initial purchase more affordable. Rebates can be fixed amounts returned to the customer at the time of the purchase or a payment that is promised to the customer over a certain time span (Eto 1996). An example of a common rebate offered today is a discount with the purchase of compact fluorescent light bulbs.

In addition, some utilities offer financial assistance with low-interest loans for efficiency improvements. However, these programs are generally small with limited budgets; therefore, the majority of utility-sponsored loan programs are first-come firstserved (Lantz 2010). Though there may be more applicants for loans than available funding, these are not utilities' most popular DSM programs. Typically, consumers would choose rebates over loans because of the instant gratification. Consequently, most utilities will allocate larger portions of their DSM budget for rebates than loans (Eto 1996). Loan programs may be more appealing in the industrial and commercial sectors that are more likely to undergo large renovations. 
Another common component of utilities' DSM program portfolios is free installations of energy efficient appliances. This program is expensive for utility companies because they cover the entire costs of the installation (Eto 1996). Free installations are usually a last resort for utility companies, and may just be advertised at times of a looming supply shortage. These free installations may also just be targeted for low-income families that may be financially unable to participate in other DSM programs.

Some utilities also offer load management programs which allow the utility to interrupt the consumer's load during peak demand hours by controlling the power supply to specific appliances on the consumer's property (Energy Information Administration 2010a). These load management programs typically cycle specific appliances (airconditioners, water heaters, etc.) during times of high demand, allowing the appliance to rotate between being on and off (Eto 1996). By cycling appliances, the utility can reduce the peak loads of their system. This program is voluntary and is usually offered to the residential sector with various incentives.

Another component of utilities' DSM program portfolios is time-based pricing programs, typically in the form of rate tariffs. Three examples of these tariffs are interruptible rates, time-of-use rates, and real-time pricing. The interruptible rates option is very similar to load management programs as the consumer is charged a lesser rate in return for curtailing his or her load when requested by the utility. Unlike load management programs, the consumer is able to determine which appliances and equipment will be turned off to decrease the load. The time-of-use rates are implemented 
by utilities which charge different rates for electricity at various times throughout the day. These prices are based on the cost of electricity generation for the utility at the different times. This tactic is used by utilities to encourage customers to alter their demand based on prices. Real-time pricing is very similar to time-of-use rates; however, the utility will forecast the prices of electricity for each hour of the day and will make the information available to the consumer in advance. Due to the large electricity demand of the commercial and industrial sectors, these three time-based pricing programs are usually directed towards these customers (Eto 1996).

\section{DSM Program Evaluations}

Evaluating and comparing energy efficiency programs throughout the U.S. is a difficult task because the energy industry is mostly regulated by state laws, which vary throughout the country. However, evaluations of DSM programs are becoming more important as there is growing interest in energy efficiency issues, and a need to prove that DSM programs are an effective option. Many investor-owned utilities are required to report their program results to their regulatory commission. Consequently, comparing the results of programs is complicated because there is variability in how utilities and states may evaluate these programs.

One complication with evaluating DSM programs is predicting consumer behavior. In order to evaluate the effectiveness of a program, the behavior of participants enrolled in the programs should be compared to how the participants would act in absence of the DSM program (Hirst et al. 1996). This second component can only be estimated with energy-use data collected from both participants and non-participants. Of 
course with predicted behavior, such as a consumer's energy use without a DSM program, there is room for error.

Another complication in evaluating DSM programs is accounting for free-riders and free-drivers. Free-riders are the participants in a program that would have engaged in the program's recommended action regardless, and free-drivers are customers that engage in the recommended action of the program but are not direct participants (Hirst et al. 1996). Therefore, calculations of the energy savings that result from these programs may be unreliable because of the complexity of determining actual participants. It is difficult to directly compare the results of DSM programs between utilities from various states because there are discrepancies about the inclusion of free-riders and free-drivers in program result calculations.

The complications with calculating free-riders are directly related to the inconsistencies of net savings definitions between states. There is not one uniform standard in the United States for calculating net savings from energy efficiency programs, and there are often even discrepancies within states. While some states adjust their gross savings to account for free-riders to determine their net savings result (e.g. California, New York), other states make different adjustments to their calculations (Hall 2008). Therefore, some study results between states are not comparable.

Additional inconsistencies between energy efficiency evaluations are in the metrics used to measure the program's performance. Two ways to measure program effectiveness are the megawatt-hours saved and megawatts shifted from the peak load, attributed to the utility's efficiency program. These calculations can also be adjusted for 
higher accuracy by including information on the utility's budget or the total number of consumers that they serve. However, utilities often calculate these results differently, and may include different program elements in their budgetary or energy savings information (Institute for Electric Efficiency 2010).

Another difficulty with obtaining accurate program evaluations is reluctance by some utilities and state regulatory commissions to provide performance calculations and results. There are multiple risks surrounding the publication including the misuse of data, complications with pending regulatory action, and a misperception of the utility's achievements in the data (Institute for Electric Efficiency 2010). However, there are also benefits of evaluation publications such as recognition and the ability to learn from other utilities' programs. Though there is variability between efficiency program evaluations, they are evolving and becoming more reliable with the growing realization that these evaluations are important. For the purpose of this study, data obtained from the Energy Information Administration (EIA) will be used. These data were reported from the individual electric utilities throughout the U.S. and calculated using the EIA's guidelines. Therefore, these data should be accurate and comparable and will be discussed further in the next chapter. 


\section{Chapter 5: Research Design}

\section{Choosing Utilities for Case Studies}

This research was conducted as a meta-study of U.S. utility companies' experiences with the implementation of energy efficiency programs. In order to observe differences between utilities and their efficiency programs, 12 case studies were developed. Within these 12 case studies, there are five utilities from states that have deregulated their electricity markets and seven from those that have not. By comparing any differences between programs in states with different levels of regulation, we may find that one level of regulation is more compatible with energy efficiency programs. In addition, there are also investor-owned and public utilities included in the study so the differences in programs can be evaluated for the various types of ownership. Also, utilities will be included from states that mandate efficiency programs and from states that do not.

The utilities chosen for this study were based on state energy efficiency rankings to attempt to include utilities from states that are seen as "efficient," and those that are considered "less efficient." The rankings being used in this research were part of the American Council for an Energy-Efficient Economy's (ACEEE) 2009 State Energy Efficiency Scorecard. This scorecard was calculated using the following policy categories: "utility-sector and public benefits programs and policies; transportation policies; building energy codes; combined heat and power; state government initiatives; and appliance efficiency standards" (American Council for an Energy-Efficient Economy 2009). These rankings were then calculated using a 50 point scale. Utilities were chosen 
for case studies from states that represent different spectrums of the state efficiency rankings.

First, utilities were chosen from Connecticut and California because both states mandate energy efficiency programs for their investor-owned and public utilities. Utilities in Connecticut and California have been cited frequently in energy efficiency literature because efficiency investments in these states have historically been high (Flanigan and Weintraub 1993; M.J. Bradley \& Associates, LLC 2009; Blumstein et al. 2005). Utility companies were also chosen for the case studies from Kansas and Alabama because they do not mandate utilities to administer efficiency programs, and overall their investments in these programs appear to be lower than other states (American Council for an Energy-Efficient Economy 2010). Therefore, utilities were chosen from these four states for comparison purposes, and both investor-owned utilities and publicly-owned utilities were selected for California and Kansas for a contrast of programs with varying ownership within and between states.

Next, public utilities that have been cited for having large DSM program portfolios were selected (Flanigan and Weintraub 1993; M.J. Bradley \& Associates, LLC 2009). Seattle City Lights in Washington and Austin Energy in Texas both have DSM program offerings that are relatively large when compared to other public utilities, and both utilities are located in states with efficiency mandates that apply to public utilities. These utility companies were also selected because there is readily available data on their programs, and what they have done to establish longstanding DSM programs should be evaluated. 
For these case studies, it is also important to have comparisons of utility efficiency programs offered by the same utility in different states. For example, Duke Energy operates in multiple states, so the utility divisions in Ohio and Indiana were selected for this study. Indiana has not deregulated its electricity market like Ohio, so Duke Energy program offerings in both states are included for comparison purposes. Likewise, Kansas City Power and Light (KCPL) has divisions in Kansas and Missouri. Utility programs offered by KCPL in both states were selected for this study because Missouri recently decided to dramatically increase funding for utility efficiency programs and Kansas decided against mandating these programs.

In addition to these selected utilities, Florida Power and Light was chosen as an investor-owned utility from a state that has not deregulated their electricity market and mandates utility efficiency programs. Since restructuring, each state that has deregulated its electricity market now mandates that utilities must achieve certain energy savings and implement energy efficiency programs. Therefore, Florida was chosen as a state that has not deregulated but still requires utilities to meet energy savings goals with cost-effective efficiency programs. With the large size of Florida Power and Light and its recent developments with DSM programs, there were available data on this utility's programs.

After utilities were selected for this study, they were organized into three groups: utilities from states that restructured their electricity industry, states that have not restructured but have efficiency mandates, and states that have not restructured and are without efficiency mandates. Within these groups, there are investor-owned utilities and public utilities. The final utilities selected for this study are shown in Table 5.1. 
Table 5.1

Utility companies in the case studies

\begin{tabular}{|c|c|c|}
\hline & Investor-Owned Utilities & Public Utilities \\
\hline $\begin{array}{c}\text { Utilities in states that } \\
\text { deregulated and have } \\
\text { efficiency mandates }\end{array}$ & $\begin{array}{c}\text {-Pacific Gas \& Electric } \\
\text {-Connecticut Light \& Power } \\
\text {-Duke Energy Ohio }\end{array}$ & $\begin{array}{c}\text {-City of Palo Alto } \\
\text { Utilities } \\
\text {-Austin Energy }\end{array}$ \\
\hline $\begin{array}{c}\text { Utilities in states that } \\
\text { did not deregulate and } \\
\text { have efficiency } \\
\text { mandates }\end{array}$ & $\begin{array}{c}\text {-Florida Light \& Power } \\
\text {-Duke Energy Indiana } \\
\text {-Kansas City Power \& Light } \\
\text { MO }\end{array}$ & $\begin{array}{c}\text {-Seattle City } \\
\text { Light }\end{array}$ \\
\hline $\begin{array}{c}\text { Utilities in states that } \\
\text { did not deregulate and } \\
\text { have no efficiency } \\
\text { mandates }\end{array}$ & $\begin{array}{c}\text {-Kansas City Power \& Light } \\
\text { KS }\end{array}$ & $\begin{array}{c}\text {-Kansas City } \\
\text { Board of Public } \\
\text { Utilities }\end{array}$ \\
\hline
\end{tabular}

It should be noted that there are no utilities in this study that are located in states with deregulated markets that do not mandate efficiency programs. All states that deregulated have some form of energy efficiency requirements (American Council for an Energy-Efficient Economy 2010).

\section{Evaluation Criteria and Data for Case Studies}

In order to directly compare the effectiveness of utility energy efficiency programs, they need to each be evaluated based on the same criteria. One of the main goals of these programs is to achieve energy savings. Therefore, the main criterion for this study is the annual energy effects (measured in mega-watt hours [MWh]) that were caused by participants in DSM programs during 2009. Energy effects are defined as the changes in a consumer's metered electricity use that reflects only activities that occur in response to utility-administered programs. It is important that non-program related changes in energy usage, such as savings from non-participants, legislated building 
improvements, and weather-cycle adjustments are excluded from the utility's energy effects calculations (Energy Information Administration 2010a). The energy effects data for this study were obtained from the EIA's Form EIA-861, the Annual Electric Power Industry Report, for the 2009 reporting period. These data are grouped by sectors including residential, commercial, and industrial.

Other key data for this study comes from the same EIA report, and it describes the annual peak load reduction. This is measured as the actual reduction in annual peak load (measured in MW) achieved by utility DSM program participants for each individual sector (Energy Information Administration 2010a). Annual peak load reduction "reflects the changes in electricity demand resulting from a DSM program that occurs at the same time of a utility's annual peak load" (Energy Information Administration 2010a). The EIA specifies that these data should account for the regular cycling of energy efficient units during the time of peak load. Many utilities concentrate on peak load reductions because it helps them meet energy demand requirements and enhances their ability to provide reliable power to all consumers.

To account for the size and scale of utilities, the number of total electricity consumers must be applied to the annual energy effects. In the EIA's Annual Electric Power Industry Report, there is another file that provides the total number of consumers for the residential, commercial, and industrial sectors of each utility. The annual energy effects should be divided by the number of consumers for each sector to adjust the data for utility size. By calculating the energy savings per consumer, larger utilities will not automatically appear to have more effective DSM programs than utilities with fewer 
consumers. Another piece of EIA data that will be used in this study is the total cost to the utilities that occurred in support of DSM programs. To calculate the amount spent by utilities on efficiency programs per consumer, the total cost needs to be divided by the total number of electricity consumers. These data may provide additional insight as to why some DSM programs save more energy than others.

Another calculation that will be performed to determine the cost-effectiveness of DSM programs is the program cost to the utility per kWh saved. To determine this, the total program cost will be divided by the combined number of $\mathrm{kWhs}$ saved from the residential, commercial, and industrial sectors. This cost per $\mathrm{kWh}$ will then be compared to the average price of one $\mathrm{kWh}$ of electricity.

In addition to the utility DSM program results reported by the EIA, qualitative information was also gathered and applied to this study. To understand all of the individual utilities' program offerings and the utilities' efficiency history, reports created by the utilities and the state public utility commissions were collected. General internet searches on the utilities' and commissions' websites were conducted to gather utility DSM program descriptions. Some of these utility studies also contain quantitative data, but since these data may be calculated in various ways by different utilities, the standard EIA data is the focus of this study. When information was not readily available on utilities' or commissions' websites, phone calls were made to these organizations to locate the proper reports. The qualitative program information will provide insight as to why some utilities had higher energy savings per consumer than other utilities. These 12 
case studies and the EIA data may also suggest possible relationships between state energy efficiency policies and utilities' experiences with DSM programs. 


\section{Chapter 6: Utility Case Studies and Results}

\section{Twelve Utility Case Studies}

Utility companies in the U.S. offer various DSM programs in their portfolios, and these differ between companies. There are also differences between utilities and their dedication to energy efficiency programs. These 12 case studies will attempt to describe each utility's DSM program portfolio and discuss recent developments in utilities' program implementation experiences. Following the case studies, the DSM program results data from the EIA will be compared between the utility companies and displayed in tables.

\section{Pacific Gas and Electric}

Pacific Gas and Electric (PG\&E) is an investor-owned utility that serves most of the northern two-thirds of California, and which offers a large DSM program portfolio. PG\&E’s 2009 Energy Efficiency portfolio included individual programs sponsored by the utility, a statewide marketing program, and government partnership programs. In addition, PG\&E's DSM portfolio has long-term strategies with complex programs that take years to design and implement, and short-term strategies such installing efficient appliances for customers (Pacific Gas and Electric Company 2010).

One of PG\&E's programs with significant energy savings is the Mass Market program. This program has an integrative approach to meet its target customers by providing incentives to upstream manufacturers and retailers who introduce residential and small business customers to the benefits of energy efficiency. As a result of the 
program, many residential and small commercial consumers began using more efficient lighting technologies, and the number of manufacturers and retailers who produce and promote these efficient products increased (Pacific Gas and Electric Company 2010).

In 2009, PG\&E focused on the implementation of projects geared towards the heavy industry and large commercial sectors. A significant portion of PG\&E's energy savings in 2009 came from heating, ventilation, and air conditioning (HVAC) equipment and process boiler efficiency improvements for these larger customer segments. There are many more opportunities for the industrial and commercial sectors to increase their energy savings with long-term investments (Pacific Gas and Electric Company 2010).

The total energy savings for PG\&E in 2009 were greatest for the commercial sector with 5,597,435 MWh. The residential sector achieved energy savings almost as large, at 4,427,506 MWh. Though PG\&E concentrated on promoting industrial sector savings in 2009, some of the long-term benefits may not have been realized yet as the industrial sector achieved the least amount of savings of the three main sectors with 1,581,895 MWh (Energy Information Administration 2010a). However, the industrial energy savings for PG\&E in 2009 are greater in comparison to the other utilities included in this study.

\section{City of Palo Alto Utilities}

The City of Palo Alto (CPAU) is a municipal utility in California that established its first energy efficiency programs in the 1970s. In 2007, great progress was made with CPAU's energy efficiency programs as the Palo Alto City Council approved CPAU's 
Ten Year Efficiency Plan, which increased energy savings targets and the budgets for electric energy efficiency programs by 50 percent (California Municipal Utilities Association 2010).

In 2009, one new program that CPAU added with additional funding was the Commercial and Industrial Energy Efficiency Program, which provides free energy audits for commercial and industrial customers with buildings larger than 30,000 square feet and/or greater than $50 \mathrm{MW}$ of electricity demand. Typical equipment installations and rebates for this program are HVAC systems, hot water systems, and lighting controls and retrofits. This program increased energy efficiency options for CPAU's commercial and industrial sectors (California Municipal Utilities Association 2010).

There were also some recent improvements to CPAU's residential programs. The Smart Energy Program is an energy efficiency incentive program for attic and roof insulation, refrigeration equipment, and appliances and lighting. In 2008, CPAU added rebates to the Smart Energy Program for residential clothes washers, which previously had no incentives. That same year CPAU chartered their Green @ Home Audits program to provide free in-home audits. With this program, the auditor installs compact fluorescent light bulbs (CFLs) and electric usage monitors. These DSM programs are all part of CPAU's recently expanded energy efficiency program portfolio (California Municipal Utilities Association 2010).

In 2009, CPAU reported annual energy savings to the EIA for residential and commercial sectors, but not the industrial sector. There was 13,347 MWh saved by the residential sector and 71,636 MWh saved by the commercial sector. With the recent 
addition of the Commercial and Industrial Energy Efficiency Program, there may be greater industrial savings in the future. The commercial energy savings for CPAU in 2009 were significant as there are 3,765 commercial customers, and approximately 19 MWh of electricity saved per commercial customer (Energy Information Administration 2010a). This is the highest commercial energy savings per customer out of all the utilities included in this study.

\section{Connecticut Light and Power}

Connecticut Light and Power (CL\&P) is an investor-owned utility company that serves residential, commercial, and industrial electric consumers throughout most of Connecticut. CL\&P's goals for its DSM programs are to reduce overall electricity demand and peak demand, reduce air pollution and $\mathrm{CO}_{2}$ emissions, and to promote economic development and energy security (Connecticut Light and Power Company 2010a). Since 1998, CL\&P is required to work with the ECMB to ensure CL\&P's DSM program portfolio is comprehensive and cost-effective.

CL\&P has the most DSM opportunities for the residential sector. Two of the most popular program components are the ENERGY STAR appliance rebates and the Central Air Conditioning and Hot Water Heater program, which have both been documented as being "overwhelmingly successful" with a growing number of participants (The Connecticut Light and Power Company et al. 2010b). CL\&P also is expanding its Home Energy Solutions (HES) program, which provides home air and duct sealing diagnostics. In 2007, HES expanded to include "weatherization and retrofitting 
existing equipment with energy-saving devices", and received national recognition as a successful residential conservation program by the ACEEE. CL\&P also offers "retrofitting for commercial and industrial sectors by replacing inefficient equipment with high-efficiency equipment, and retrofitting existing equipment with new modifications and controls" (The Connecticut Light and Power Company et al. 2010b).

In 2009, CL\&P's DSM programs' energy savings were the greatest for the commercial sector and totaled 1,514,196 MWh. The industrial and residential sectors achieved large annual energy savings that were reported as 586,353 MWh and 574,316 MWh respectively (Energy Information Administration 2010a). Though CL\&P offers the most specific DSM programs for the residential sector, there are many opportunities for commercial and industrial sectors to make efficiency improvements.

\section{Austin Energy}

Austin Energy is a large municipal utility in Texas that offers nationally recognized DSM programs to residential, commercial, and industrial sectors. ENERGY STAR acknowledged Austin Energy for its Home Rebate Program as over 5,000 customers in 2008 took advantage of the low-interest loans and rebates for energy efficiency improvements. Austin Energy was recognized for having an effective rebate program and meeting its participation goal (Austin Energy 2008).

However, the residential program that contributed the most energy savings in 2009 for Austin Energy was the CFL Program, which saved approximately 13,890 MWh of electricity. Austin Energy was providing $\$ 2$ to $\$ 4$ rebates coupons to customers for the 
purchase of CFLs, and local retailers partnered with Austin Energy to accept these coupons. These retailers then sent the collected coupons back to Austin Energy and were fully reimbursed. The energy savings goal for the CFL Program was 1,263 MWh which was greatly surpassed. Though this program was very successful in 2009 , it was only meant to be a temporary program and has since been discontinued (Austin Energy 2010).

The program that accumulated the greatest total annual energy savings for Austin Energy in 2009 was the Commercial Rebate Program. Rebates were offered to businesses for the purchase of new energy efficient appliances such as lighting, HVAC, thermal cool storage, motors, and other technologies. These incentive rebates of 20 percent effectively increased DSM participation for the commercial sector. Though the program's energy savings were large when compared to other DSM program components, the program's goals were not met as it only saved 90 percent of the target savings of 33,398 MWh (Austin Energy 2010).

Austin Energy reported annual energy savings to the EIA that were relatively high in comparison to other utilities in this study. Residential energy savings reported in 2009 were 307,000 MWh, and commercial sector savings were 351,110 MWh (Energy Information Administration 2010a). These energy savings are similar to Seattle City Light's, the other large municipal utility in this study. Austin Energy also reported $137,000 \mathrm{MWh}$ industrial energy savings, which is significant since the company has only 80 industrial customers.

\section{Duke Energy Ohio}


Duke Energy is an investor-owned electric and natural gas utility company that serves residential, commercial, and industrial sectors in Ohio, Indiana, North Carolina, South Carolina, and Kentucky. Duke Energy Ohio was the first utility of the franchise to approve the new energy efficiency framework in 2008. This regulatory model allows Duke Energy to earn a return on its investment in energy efficiency products and services that help customers reduce electricity consumption. Duke Energy only receives payment if its energy efficiency programs "actually help customers conserve power, as verified by an independent third-party" (Duke Energy 2010). This framework is supposed to provide an incentive for Duke Energy utilities to reduce their electricity sales.

Since the implementation of the energy efficiency framework in Ohio, the DSM program portfolio has expanded. One example of a program that is now available to the residential sector is the Power Manager Program, which pays customers annually for volunteering to have their air conditioners cycled on and off on certain summer days (Duke Energy 2010). This program helps Duke Energy Ohio reduce its peak demand and provide reliable electricity service. Other residential programs in Ohio include common programs such as home energy audits, free low-income weatherization, and energy efficient appliance rebates. For the commercial and industrial sectors, Duke Energy Ohio also offers rebates for energy efficient equipment such as HVAC systems, lighting, motors, and pumps (Duke Energy 2010).

Of all of the utilities included in this study that are located in states with deregulated electricity markets, Duke Energy Ohio reported the least amount of annual energy savings to the EIA in 2009. Energy efficiency programs in Ohio helped the 
residential sector achieve 47,532 MWh of electricity savings. In addition, Duke Energy Ohio reported 240,489 MWh energy savings by the commercial sector, and 104,759 MWh by the industrial sector (Energy Information Administration 2010a).

\section{Seattle City Light}

Seattle City Light is one of the largest municipal utilities in the U.S. and has invested in energy efficiency since 1977; it is the U.S. utility with the longest, continuously operating energy efficiency program. Seattle City Light is also nationally recognized as having one of the most effective energy efficiency programs in North America (Seattle City Light 2008). This long-term commitment to energy efficiency continues to encourage Seattle City Light to improve its DSM portfolio.

In 2008, Seattle City Light implemented a new Conservation Five-Year Plan with the goal of meeting most projected load-growth through energy efficiency by 2012. Seattle City Light acknowledges that energy efficiency is a long-term financial commitment and greater investments will need to be made for DSM programs to meet the Conservation Five Year Plan's goal (Seattle City Light 2008).

Part of Seattle City Light's new energy efficiency framework includes expanding its DSM program portfolio for each of the three major sectors. With this plan, new programs were added for the commercial sector such as construction design consultation, whole-building energy analysis, and new energy efficiency incentives for schools. In addition, the plan added new rebates for simple compressors for small and medium sized industrial businesses. The residential sector also received increased incentives for 
investments in energy efficient appliances, lighting, weatherization, and construction. In 2009, the greatest accomplishment of Seattle City Light's DSM programs was the distribution of one million CFLs saving up to 35 million $\mathrm{kWh}$ of electricity. To expand its DSM program portfolio and achievements, Seattle City Light increased its energy efficiency budget to $\$ 35,810,000$ in 2009 (Seattle City Light 2009).

Seattle City Light offers the most DSM opportunities to the residential sector, and this sector achieved the greatest number of annual energy savings in 2009 with 330,685 MWh. The commercial and industrial sectors also achieved energy savings of 259,942 MWh and 49,923 MWh, respectively (Energy Information Administration 2010a). When compared to the other utilities in this study, Seattle City Light has some of the highest MWhs saved per consumer for the residential and industrial sectors.

\section{Duke Energy Indiana}

In 2010, Duke Energy Indiana implemented the same new energy efficiency framework that Duke Energy Ohio implemented in 2008. When comparing the DSM program portfolio between Duke Energy Ohio and Indiana, the program components are very similar. For example, Duke Energy Indiana began promoting the same Power Manager program actively in 2009, and was able to enroll 5,853 new customers (Indiana Regulatory Commission 2010b). Another successful program component for Duke Energy Indiana in 2009 was the Smart Saver Program. This program features incentives for high efficiency heating and cooling equipment. The participation for Smart Saver grew rapidly as the number of participants who purchased high efficiency heaters and air 
conditioners increased 28 percent and 104 percent, respectively (Indiana Regulatory Commission 2010b).

Duke Energy Indiana achieved higher annual energy savings for each sector in 2009 than did the Ohio division. The commercial sector had the highest annual energy savings with 328,723 MWh. Though this is greater than the commercial energy savings by Duke Energy Ohio, the Indiana division saved less energy per commercial customer than Ohio. For the other two sectors, Duke Energy Indiana achieved higher annual energy savings and higher savings per consumer than did the Ohio division. The total annual energy savings for the residential sector was $151,811 \mathrm{MWh}$, and 240,410 for the industrial sector (Energy Information Administration 2010a).

\section{Florida Power and Light}

Florida Power and Light (FP\&L) is an investor-owned utility in Florida that serves large residential and commercial sectors and a limited industrial sector. FP\&L has a high proportion of residential and commercial customers dependent on electricity for cooling, as Florida has the highest number of days requiring cooling in the continental U.S (Florida Public Service Commission 2011). FP\&L sells the most electricity of all the investor-owned electric utilities in Florida.

Since the Florida Public Service Commission set new goals for FP\&L’s DSM programs for 2005-2014, FP\&L modified its DSM program portfolio. In 2007, FP\&L added the Residential Load Control program to reduce peak demand. In exchange for monthly bill credits, this program offers load control to residential customers for 
household appliances. By installing direct load control equipment in customers' homes, FP\&L controls customer energy loads as needed (Florida Public Service Commission 2008). Reducing peak loads is important in Florida as many people have the need to operate their air conditioners during the same hours. The annual peak demand savings for the residential sector in 2009 was 1,479 MW, the highest of all utilities included in this study (Energy Information Administration 2010a).

FP\&L has the second highest 2009 annual energy savings of all utilities in this study, next to PG\&E, for both the residential and commercial sectors. Residential energy savings for FP\&L were 2,131,579 MWh, and commercial savings were 1,956,728 MWh (Energy Information Administration 2010a). Though these total annual energy savings appear relatively high to other utilities, the results are not as impressive when compared to the high number of customers that FP\&L serves. In 2009, FP\&L did not report any industrial energy savings to the EIA.

\section{Kansas City Power and Light Missouri}

Kansas City Power and Light (KCP\&L) is an investor-owned utility operating in Missouri and Kansas. KCP\&L implemented its current DSM program portfolio beginning in 2005. Filings for energy efficiency programs were made around the same time in Kansas and Missouri to keep the programs consistent throughout KCP\&L's service area (Kansas Corporation Commission 2011). All of the energy efficiency programs that were filed in Missouri were approved by the Missouri Public Service Commission. 
During 2005, the Change a Light program was KCP\&L's first program filed and approved in Missouri. This program has since changed its name to "Lighting the Future." In 2009, the program had record participation and 44,811 CFLs were distributed. To achieve these high levels of participation, KCP\&L Missouri used a markdown approach at Home Depot and door-to-door delivery of CFLs (Kansas Corporation Commission 2011). This program was never implemented in Kansas.

KCP\&L Missouri only reported annual energy savings for the residential and commercial sectors to the EIA. In 2009, KCP\&L Missouri's residential sector saved 6,801 MWh, and the commercial sector saved 9,986 MWh (Energy Information Administration 2010a). KCP\&L has limited energy efficiency programs for the industrial sector.

\section{Kansas City Power and Light Kansas}

KCP\&L Kansas has not implemented all of the DSM program components that exist in Missouri; only eight of the ten programs in the 2005 energy efficiency plan were implemented. Both the Change a Light and Home Performance ENERGY STAR programs were denied by the Kansas Corporation Commission. However, Kansas has a unique program called Efficiency Kansas which is a revolving loan program for energy efficiency improvements in homes and small businesses. This program is funded by approximately \$34 million of the 2009 American Recovery and Reinvestment Act funds (Kansas Corporation Commission 2011). 
When comparing the total 2009 DSM program participation data between KCP\&L's Missouri and Kansas divisions, Missouri has a much higher total participation number. However, approximately 44,800 of Missouri’s 53,800 participants were part of the Change a Light program. The Kansas division's 2009 DSM programs had approximately 12,800 participating customers, without any participants in the Change a Light program. The Kansas division had approximately 2,000 more participants than Missouri for both the Home Energy Analyzer and Cool Homes programs (Kansas Corporation Commission 2011).

Similar to Missouri, the Kansas division of KCP\&L reported 2009 annual energy savings to the EIA for the residential and commercial sectors. Energy savings for each sector were greater in Kansas than in Missouri. The residential sector saved 24,036 MWh, and the commercial sector saved 59,377 MWh (Energy Information Administration 2010a). The Kansas division also reported less residential and commercial customers to the EIA than the Missouri division, suggesting that KCP\&L Kansas has higher annual energy savings per customer.

\section{Kansas City Board of Public Utilities}

The Kansas City Board of Public Utilities (KCBPU) is a municipal utility that serves approximately 65,000 electricity consumers in Kansas. Though KCBPU offers some energy efficiency tips and programs, these are limited in comparison to other utilities in this study. KCBPU offers low-income weatherization and some ENERGY STAR rebates for air conditioners and heat-pumps to home-owners, renters, and small 
businesses on a first-come first-serve basis. KCBPU also encourages the use of the Carbon Footprint Calculator that was designed by The Greater Kansas City Chamber of Commerce and helps people identify ways to reduce their energy use and carbon footprint. In addition, the KCBPU has a newsletter with energy efficiency tips (Kansas City Board of Public Utilities 2010).

The 2009 annual energy effects that KCBPU reported to the EIA were the lowest compared to the other utilities in this study. KCBPU did not report residential or industrial annual effects, but the commercial sector saved 2,009 MWh. The KCBPU also reported that the residential sector reduced peak demand by $3 \mathrm{MW}$, and the commercial sector reduced peak demand by 1 MW (Energy Information Administration 2010a).

\section{Alabama Power}

Alabama Power is the only investor-owned utility operating in Alabama, and the company offers less DSM program options than most other utilities included in this study. Alabama Power sponsors a few of the typical DSM programs that most electric utilities promote, such as a $\$ 20$ rebate for the purchase of qualifying ENERGY STAR air conditioners, and an Energy Check-up online system that uses consumers' bills to identify ways to save energy (Alabama Power 2011).

Compared to the other utilities included in this thesis, Alabama Power reported some of the lowest annual energy savings per customer for the residential and commercial sectors. In 2009, Alabama Power reported energy savings of 14,913 MWh by the residential sector. Given Alabama Power's relatively high number of residential 
customers, it has the lowest reported energy savings per customer. Also, Alabama Power's commercial sector saved approximately $88,301 \mathrm{MWh}$, and no data were reported for the industrial sector (Energy Information Administration 2010a).

In the next section of this chapter, tables are presented that contain the data each utility reported to the EIA for various program result criteria such as: annual energy effects for each sector, annual peak demand savings for each sector, and total costs of DSM programs to the utilities. To adjust for varying utility size, the annual energy effects, total peak demand reduction, and total costs will also be divided by the number of customers that each utility serves.

\section{DSM Program Results}

The tables in this section contain DSM program results reported to the EIA, which help demonstrate the effectiveness of these programs (Energy Information Administration 2010a). The annual energy effects for each sector are the energy savings caused by new and existing participants in DSM programs throughout the year. Tables 6.1, 6.2, and 6.3 depict the annual energy effects that the utilities reported to the EIA for 2009 for the three major sectors. These data were then adjusted by the number of customers in each sector to account for the size of the utility, and sorted by the greatest to least energy savings per customer. 
Table 6.1

Residential sector 2009 annual energy effects from DSM programs (MWh)

\begin{tabular}{|c|c|c|c|}
\hline Utilities* & $\begin{array}{c}\text { Res. Annual } \\
\text { Energy Effects }\end{array}$ & \# of customers & Savings/customer \\
\hline PG\&E & $4,427,506$ & $4,574,196$ & 0.968 \\
\hline Seattle City Light & 330,685 & 355,097 & 0.931 \\
\hline Austin Energy & 307,000 & 364,554 & 0.842 \\
\hline CL\&P & 574,316 & 990,638 & 0.579 \\
\hline City of Palo Alto & 13,347 & 24,863 & 0.537 \\
\hline FP\&L & $2,131,579$ & $3,986,227$ & 0.535 \\
\hline Duke Energy IN & 151,811 & 672,740 & 0.225 \\
\hline KCPL-KS & 24,036 & 211,289 & 0.114 \\
\hline Duke Energy OH & 47,532 & 580,329 & 0.082 \\
\hline KCPL-MO & 6,801 & 239,070 & 0.028 \\
\hline Alabama Power & 14,913 & $1,228,000$ & 0.012 \\
\hline KCBPU & n/a & 56,699 & \\
\hline
\end{tabular}

*mandated efficiency programs in bold, programs not mandated in normal font public utilities in italics, investor-owned utilities in normal font

Source: Energy Information Administration 2010a

Table 6.2

Commercial sector 2009 annual energy effects from DSM programs (MWh)

\begin{tabular}{|c|c|c|c|}
\hline Utilities* & $\begin{array}{c}\text { Comm. Annual } \\
\text { Energy Effects }\end{array}$ & $\begin{array}{c}\text { \# of } \\
\text { customers }\end{array}$ & savings/customer \\
\hline City of Palo Alto & 71,636 & 3,765 & 19.027 \\
\hline CL\&P & $1,514,196$ & 84,276 & 17.967 \\
\hline PG\&E & $5,597,435$ & 639,851 & 8.748 \\
\hline Austin Energy & 351,100 & 44,747 & 7.846 \\
\hline Seattle City Light & 259,942 & 39,411 & 6.596 \\
\hline FP\&L & $1,956,728$ & 504,611 & 3.878 \\
\hline Duke Energy OH & 240,489 & 70,396 & 3.416 \\
\hline Duke Energy IN & 328,723 & 100,591 & 3.268 \\
\hline KCPL-KS & 59,377 & 26,533 & 2.238 \\
\hline Alabama Power & 88,301 & 201,701 & 0.438 \\
\hline KCPL-MO & 9,986 & 31,307 & 0.319 \\
\hline KCBPU & 2,009 & 7,102 & 0.283 \\
\hline
\end{tabular}

*mandated efficiency programs in bold, programs not mandated in normal font public utilities in italics, investor-owned utilities in normal font

Source: Energy Information Administration 2010a 
Table 6.3

Industrial sector 2009 annual energy effects from DSM programs (MWh)

\begin{tabular}{|c|c|c|c|}
\hline Utilities* & $\begin{array}{c}\text { Ind. Annual } \\
\text { Energy Effects }\end{array}$ & $\begin{array}{c}\text { \# of } \\
\text { customers }\end{array}$ & savings/customer \\
\hline Austin Energy & 137,000 & 80 & 1712.5 \\
\hline PG\&E & $1,581,895$ & 1,124 & 1407.380 \\
\hline Seattle City Light & 49,923 & 220 & 226.923 \\
\hline CL\&P & 586,353 & 2,821 & 207.853 \\
\hline Duke Energy IN & 240,410 & 2,814 & 85.434 \\
\hline Duke Energy OH & 104,759 & 2,115 & 49.531 \\
\hline City of Palo Alto & $\mathrm{n} / \mathrm{a}$ & 202 & \\
\hline FP\&L & $\mathrm{n} / \mathrm{a}$ & 11,517 & \\
\hline KCPL-MO & $\mathrm{n} / \mathrm{a}$ & 1,093 & \\
\hline KCPL-KS & $\mathrm{n} / \mathrm{a}$ & 1,004 & \\
\hline KCBPU & $\mathrm{n} / \mathrm{a}$ & 95 & \\
\hline Alabama Power & $\mathrm{n} / \mathrm{a}$ & 5,910 & \\
\hline
\end{tabular}

*mandated efficiency programs in bold, programs not mandated in normal font public utilities in italics, investor-owned utilities in normal font

Source: Energy Information Administration 2010a

By reviewing these annual energy effects tables, the four utilities that generally seem to have the highest energy savings per customer are PG\&E, Austin Energy, Seattle City Light, and CL\&P. The utilities that have the lowest energy savings per customer appear to be both divisions of KCP\&L, Alabama Power, and KCBPU.

The next set of DSM program results is the peak demand savings for each of the three major sectors (Table 6.4). The peak demand savings are the annual reductions in peak load that were achieved by DSM program participants. To account for utility size, the total peak demand reduction of all three sectors was then divided by the total number of customers and ranked from greatest to least. 
Table 6.4

2009 annual peak demand reductions by sector (MW)

\begin{tabular}{|c|c|c|c|c|}
\hline Utilities* & $\begin{array}{c}\text { Res. Peak } \\
\text { Reduction }\end{array}$ & $\begin{array}{c}\text { Comm. Peak } \\
\text { Reduction }\end{array}$ & $\begin{array}{c}\text { Ind. Peak } \\
\text { Reduction }\end{array}$ & $\begin{array}{c}\text { Total Peak Demand } \\
\text { Reduction/Customers }\end{array}$ \\
\hline Austin Energy & 196 & 107 & 42 & 0.0008 \\
\hline FP\&L & 1,479 & 748 & $\mathrm{n} / \mathrm{a}$ & 0.0005 \\
\hline CL\&P & 64 & 356 & 79 & 0.0004 \\
\hline PG\&E & 865 & 1,118 & 223 & 0.0004 \\
\hline City of Palo Alto & 0 & 10 & $\mathrm{n} / \mathrm{a}$ & 0.0003 \\
\hline Duke Energy IN & 56 & 82 & 34 & 0.0002 \\
\hline Seattle City Light & 40 & 31 & 6 & 0.0002 \\
\hline $\begin{array}{c}\text { Duke Energy } \\
\text { OH }\end{array}$ & 9 & 48 & 13 & 0.0001 \\
\hline KCPL-KS & 16 & 9 & $\mathrm{n} / \mathrm{a}$ & 0.0001 \\
\hline Alabama Power & 7 & 84 & $\mathrm{n} / \mathrm{a}$ & $6.338 \mathrm{E}-05$ \\
\hline KCBPU & 3 & 1 & $\mathrm{n} / \mathrm{a}$ & $6.260 \mathrm{E}-05$ \\
\hline KCPL-MO & 4 & 2 & $\mathrm{n} / \mathrm{a}$ & $2.210 \mathrm{E}-05$ \\
\hline
\end{tabular}

*mandated efficiency programs in bold, programs not mandated in normal font public utilities in italics, investor-owned utilities in normal font

Source: Energy Information Administration 2010a

These data suggest that the utilities with the greatest peak load reductions from DSM programs are PG\&E, FP\&L, and Austin Energy. The utilities with the lowest peak load reductions are KCPL-MO and KCBPU.

Table 6.5 consists of the total costs of DSM programs to the utilities, the total number of customers that each utility serves, and the utilities' cost of DSM programs per customer. The total costs of DSM programs to the utilities include direct costs, indirect costs, incentives, and load management programs (Energy Information Administration 2010a). The total customers are a combination of the customer data for residential, commercial, and industrial sectors. 
Table 6.5

2009 total utility cost of energy efficiency programs per customer (\$)

\begin{tabular}{|c|c|c|c|}
\hline Utilities* & $\begin{array}{c}\text { Total Cost to } \\
\text { Utility }(\$)\end{array}$ & Total Customers & Cost/Customer \\
\hline PG\&E & $523,066,000$ & $5,215,171$ & 100.297 \\
\hline KCPL-KS & $18,779,000$ & 238,826 & 78.630 \\
\hline Seattle City Light & $30,502,000$ & 394,728 & 77.273 \\
\hline City of Palo Alto & $1,786,000$ & 28,830 & 61.949 \\
\hline CL\&P & $53,260,000$ & $1,077,735$ & 49.418 \\
\hline Austin Energy & $19,212,000$ & 409,381 & 46.929 \\
\hline FP\&L & $186,052,000$ & $4,502,355$ & 41.323 \\
\hline Alabama Power & $56,257,000$ & $1,435,611$ & 39.187 \\
\hline KCPL-MO & $6,614,000$ & 271,470 & 24.364 \\
\hline Duke Energy OH & $13,255,000$ & 652,840 & 20.304 \\
\hline Duke Energy IN & $6,617,000$ & 776,145 & 8.525 \\
\hline KCBPU & 255,000 & 63,896 & 3.991 \\
\hline
\end{tabular}

*mandated efficiency programs in bold, programs not mandated in normal font public utilities in italics, investor-owned utilities in normal font

Source: Energy Information Administration 2010a

By reviewing these data, some of the total costs per customer results seem consistent with the rest of the data, and others seem inconsistent. PG\&E had some of the highest energy savings and peak load reductions, so it seems reasonable that they spend more on energy efficiency programs per customer than the other utilities. However, KCPL Kansas has some of the lowest DSM program results, and the second highest total costs per customer. The possible reasons for this will be discussed in the next chapter.

Table 6.6 below demonstrates the cost-effectiveness of these programs by presenting the cost of DSM programs to utilities divided by the number of $\mathrm{kWhs}$ saved. This will help to determine if these programs are economically beneficial for utilities. 
Table 6.6

2009 total utility cost of energy efficiency programs per $\mathrm{kWh}$ saved by the utility (\$)

\begin{tabular}{|c|c|c|c|}
\hline Utilities* & Total Cost & Total $\mathrm{kWh}$ & Cost/kWh \\
\hline Duke Energy IN & $6,617,000$ & $720,944,000$ & 0.009 \\
\hline CL\&P & $53,260,000$ & $2,674,865,000$ & 0.02 \\
\hline City of Palo Alto & $1,786,000$ & $84,983,000$ & 0.021 \\
\hline Austin Energy & $19,212,000$ & $795,100,000$ & 0.024 \\
\hline Duke Energy OH & $13,255,000$ & $392,780,000$ & 0.034 \\
\hline PG\&E & $523,066,000$ & $11,606,836,000$ & 0.045 \\
\hline FP\&L & $186,052,000$ & $4,088,307,000$ & 0.046 \\
\hline Seattle City Light & $30,502,000$ & $640,550,000$ & 0.048 \\
\hline KCBPU & 255,000 & $2,009,000$ & 0.127 \\
\hline KCP\&L KS & $18,779,000$ & $83,413,000$ & 0.225 \\
\hline KCP\&L MO & $6,614,000$ & $16,787,000$ & 0.394 \\
\hline Alabama Power & $56,257,000$ & $103,214,000$ & 0.545 \\
\hline
\end{tabular}

*mandated efficiency programs in bold, programs not mandated in normal font public utilities in italics, investor-owned utilities in normal font

Source: Energy Information Administration 2010a

When comparing the cost per $\mathrm{kWh}$ saved from energy efficiency programs to the cost of generating one $\mathrm{kWh}$ of electricity, the cost-effectiveness results vary depending on the utility and fuel source. In 2009, the average cost of generating one $\mathrm{kWh}$ of electricity was approximately three cents per kWh. Specifically, the cost of electricity generation from coal was around three cents per $\mathrm{kWh}$, gas was five cents per $\mathrm{kWh}$, and nuclear power was around two cents per kWh (Nuclear Energy Institute 2010).

Therefore, energy efficiency programs were cost-effective for at least four of the utilities included in the study because conserving one $\mathrm{kWh}$ of electricity cost less than generating one $\mathrm{kWh}$. However, it is important to note that power plants differ and the cost of electricity generation is variable. Energy efficiency programs may have been costeffective for more than four utilities, but they were not cost-effective for KCBPU, 
KCP\&L Missouri and Kansas, and Alabama Power. In the next chapter, some apparent trends and possible explanations for these results will be discussed. 


\section{Chapter 7: Discussion, Recommendations and Conclusions}

\section{Discussion}

The utilities' results for their 2009 DSM programs are relatively consistent throughout criteria and sectors. PG\&E has the most annual energy savings in the residential, commercial, and industrial sectors of the selected utilities, and also ranks highly for energy savings per customer in each sector. In 2009, PG\&E spent the most money per customer on efficiency programs compared to the other selected utilities. This may be due to California's dedication to energy efficiency since the 1970s. With the state government defining efficiency goals for utilities, California continues to emphasize the importance of energy efficiency. California state policies may be one of the reasons that PG\&E invests the most in DSM programs of all the utilities included in this study. For example, PG\&E may invest more in these programs because of the ambitious statewide energy savings target for investor-owned utilities of 23 billion $\mathrm{kWh}$ between 2004 and 2009 (American Council for an Energy-Efficient Economy 2010).

The three other utilities that have relatively high annual energy savings for the major sectors are CL\&P, Austin Energy, and Seattle City Light. CL\&P is similar to PG\&E as they are both investor-owned utilities in states with mandated efficiency programs. Through working with the ECMB to develop energy efficiency programs, Connecticut utilities are required to pursue cost-effective efficiency options. This is similar to the requirements of investor-owned utilities in California. Therefore, CL\&P's DSM program effectiveness may be attributed to Connecticut's efficiency standards. However, it is possible that CL\&P would continue to invest in DSM programs if it was 
not mandated to do so but found these programs to be cost-effective. This may be likely since Table 6.6 suggests that DSM programs are cost-effective for CL\&P.

Austin Energy and Seattle City Light are comparable as they are both large public utilities and achieved similar energy savings results. Also, both utilities have been nationally recognized for their energy efficiency programs and continue to add new programs to their portfolios. In addition, Seattle City Light and Austin Energy are able to offer competitive rates to their customers, possibly because of their large customer base and the use of energy efficiency to meet electricity demand (Seattle City Light 2009; Austin Energy 2008). Though Seattle City Light and Austin Energy are public utilities, both companies are mandated to pursue energy efficiency options (American Public Power Association 2011). However, both utilities may be likely to invest in DSM programs without mandates because of the economic and societal benefits. Table 6.6 also suggests that DSM programs are cost-effective for Austin Energy, and possibly for Seattle City Light.

There were also programs in this study that had lower results from their DSM programs. One example is KCBPU; as a small public utility in Kansas, it offers very few energy efficiency programs compared to Seattle City Light and Austin Energy. In 2009, KCBPU only reported annual commercial energy savings to the EIA. Though it offers few energy efficiency programs to the residential and commercial sectors, it is unclear why there were no residential program results. Also, KCBPU invested the least per customer in its energy efficiency programs, and these programs did not appear to be costeffective. 
The City of Palo Alto is an even smaller public utility than KCBPU, but it achieved higher energy savings and invested more money in DSM programs in 2009 (Energy Information Administration 2010a). This may be because the City of Palo Alto is in California and its customers expect more energy efficiency programs than customers in Kansas. Also, California mandates public utilities to provide energy efficiency programs and set their own energy savings targets. This state policy may have influenced the effectiveness of the City of Palo Alto's DSM program, as it was much more costeffective than KCBPU's program. However, more studies comparing public utilities in these states would need to be conducted to determine this.

Some investor-owned utilities also have less-effective DSM programs; KCP\&L, in both Kansas and Missouri, and Alabama Power were consistently in the bottom half of the rankings of the utilities' annual energy savings per customer for each sector. Also, none of these utilities were particularly effective at reducing annual peak demand, though Alabama Power did decrease commercial peak demand by 84 MW (ranking fifth in this study for that sector). In addition, their programs did not appear to be cost-effective.

Both Alabama Power and KCP\&L Missouri were also in the lower half of the utility rankings for money spent on energy efficiency programs per customer. This seems consistent with the rest of the results; however, KCP\&L Kansas was second to PG\&E for total utility DSM costs per customer. By investing more in energy efficiency programs per customer, one may expect that KCP\&L Kansas would have achieved higher annual energy savings and peak demand reduction results. It is possible that KCP\&L Kansas recently increased its spending and the program benefits have not yet developed. This 
would explain why KCP\&L Kansas’s DSM program was not cost-effective in 2009. More research needs to be conducted on DSM program costs to utilities and energy savings results to determine if there is a correlation and if KCP\&L Kansas's spending level is significant.

In comparison to utilities with higher annual energy savings per customer, KCP\&L and Alabama Power are in states with fewer energy efficiency regulations. Kansas and Alabama are the two states included in this study that do not mandate any form of utility energy efficiency programs. In 2009, Missouri passed legislation requiring utilities to pursue cost-effective energy efficiency opportunities. Before this legislation, Missouri did not require utility energy efficiency options. Therefore, it may have been too early for the influence of that legislation to be reflected in $\mathrm{KCP} \& \mathrm{~L}$ Missouri's 2009 annual energy savings results. However, a larger sample is needed to determine the correlation between state efficiency mandates and the effectiveness of utility DSM programs.

Similar to KCP\&L and Alabama Power, Duke Energy is an investor-owned utility that generally ranked in the bottom half of the selected utilities for energy savings per customer. In 2009, Duke Energy Ohio and Indiana had fewer annual energy savings per customer for each sector than PG\&E, CL\&P, Seattle City Light, Austin Energy, City of Palo Alto, and FP\&L (the last two utilities did not report industrial data). This may be related to Duke Energy Ohio and Indiana having the lowest total DSM program costs per customer of all the investor-owned utilities; however, a larger sample is needed to determine the significance of total utility DSM costs per customer. Duke Energy adopted 
its new energy efficiency framework in Ohio during 2008 and in Indiana during 2010. Therefore, Duke Energy's DSM programs may be more influential in the future as the utilities strive to meet these higher standards.

FP\&L is another investor-owned utility that seemed to have modest results for most categories in this study. FP\&L was especially effective at reducing the peak demand of residential and commercial sectors. This seems consistent with the goals of FP\&L as it stresses the importance of reducing peak demand and providing reliable power. FP\&L is located in Florida, one of the states with the most cooling degree days, and it is required to work with customers to reduce demand during peak times. FP\&L had the greatest residential peak demand reduction of all the selected utilities, and the second highest total peak demand reduction per customer. This is significant because FP\&L did not report any peak demand savings for the industrial sector which was included in the total peak demand reduction calculation. Therefore, FP\&L's peak demand savings per customer for the residential and commercial sectors was relatively high.

One weakness of the data is that only half of the selected utilities reported energy savings data for the industrial sector to the EIA (Energy Information Administration 2010a). This may be because most DSM programs are still focused on residential and commercial sectors, among various other unknown reasons. After observing recent changes to DSM program portfolios, it seems that some utilities are beginning to invest more money in industrial sector efficiency programs. In the future, there may be more energy efficiency results for the industrial sector. 
Overall, the DSM program results from the selected utilities seem logical. For each sector, typically the same utilities were in the top and bottom halves of the rankings for annual energy effects per customer. These rankings of the utilities also seemed to coincide with the ACEEE 2009 State Energy Efficiency Scorecard rankings. KCBPU, KCP\&L, and Alabama Power were the three utilities with the lowest energy savings results per customer, and Kansas, Missouri, and Alabama rank between 39 and 48 of the 51 spots included in the ACEEE 2009 state efficiency rankings (American Council for an Energy Efficient Economy 2009). In addition, these utilities had the least cost-effective DSM programs.

Similarly, PG\&E overwhelmingly had the highest energy efficiency program results, and California is atop the ACEEE's list of efficient states. In the 2009 ACEEE rankings, of the states including utilities in this study, California was followed by Connecticut, Washington, Florida, and Texas ranging from numbers 3 to 23 respectively. When determining the state efficiency rankings, the ACEEE State Efficiency Scorecard gives the most weight to the Utility and Public Benefits Efficiency Programs and Policies score. Therefore, it seems consistent that states including utilities with more effective DSM programs would rank relatively high.

From the limited sample of utilities in this study, there were no obvious differences between investor-owned and public utilities results; utilities with both types of ownership had high and low energy savings results. From this small sample, it is difficult to determine if public utilities are more likely to have effective DSM programs because there were three public utilities with successful programs and one, KCBPU, with 
an ineffective program. One difference between these public utilities is that Seattle City Light, Austin Energy, and the City of Palo Alto are located in states with efficiency mandates for public utilities and KCBPU is not. Also, deregulation seems to have no effect on the success of public utilities' DSM programs as Washington did not deregulate and Seattle City Light has an effective program. However, it is important to note that it was a very small sample of public utilities.

In this study, the two smaller public utilities reported fewer energy savings results than the large public utilities. This may be because the larger utilities have more customers to absorb program costs and can invest more in energy efficiency. Small municipal utilities are at a disadvantage because they have fewer resources, and depending on utility staff size, they may have less experience with DSM programs (Wilson et al. 2008). Therefore, it may be more difficult for small municipal utilities to develop effective DSM programs. However, a larger sample of public utilities would need to be studied in detail to determine this.

A major difference between states that deregulated their electricity market and those that did not is that the states that deregulated all have some sort of energy efficiency requirements. Due to these efficiency mandates, there is no longer concern over states with a deregulated electricity market abandoning energy efficiency programs (American Council for an Energy Efficient Economy 2010). Investor-owned utilities in these states, such as CL\&P and PG\&E, typically had higher energy savings results, though Duke Energy Ohio did not. Therefore, some of these states with longstanding dedication to energy efficiency, like California and Connecticut, seem to have more effective utility 
DSM programs. However, there needs to be more research regarding utility DSM program effectiveness and state policies to determine a correlation.

\section{Policy Recommendations}

To increase DSM program energy savings results, states should mandate utilities to provide these programs and meet certain targets. In this study, utilities located in states with energy efficiency requirements had more energy savings than utilities in states without requirements. In addition, all of these utilities located in states with efficiency mandates had more cost-effective DSM programs. Though this was only a small sample of utilities in the U.S., it is logical that utilities would have more incentive to invest in energy efficiency if they were held accountable by the state government.

One state policy that may be beneficial to energy efficiency programs is performance based incentives for utilities meeting energy savings targets. Typically when states establish these requirements, utilities meet or exceed the goals (Hayes et al. 2011). Energy efficiency programs need to be profitable to investor-owned utilities, and states could use shareholder incentives to accomplish this. There are different types of shareholder incentives such as: shared benefits, where utilities can earn benefits from the positive difference between their efficiency program spending and the program's benefits; performance incentives, in which utilities are rewarded for meeting preestablished energy savings goals; and rate of return, where utilities can earn a rate of return equal to energy efficiency spending or savings (Hayes et al. 2011). These mechanisms can help lower the barrier between utility profits and energy efficiency. 
Both the data from this thesis and a study by the ACEEE suggest that states with shareholder incentives typically have utilities spending more per customer on energy efficiency programs than states without incentives (Hayes et al. 2011).

Of the states with utilities included in this thesis, all but Alabama and Kansas now have set some sort of energy efficiency requirements and standards for utilities. Most of the states that require energy efficiency programs use some form of shareholder incentives; these states include California, Connecticut, Ohio, Texas, and Washington (Hayes et al. 2011). Since these states include utilities with effective DSM programs, other states should consider these incentives to increase utilities' investments in energy efficiency. However, attributing energy savings success to one policy mechanism or program component is extremely difficult to do with the variability of policies and programs in the U.S.

Public utilities' energy efficiency programs could also benefit from state policies mandating energy savings goals and providing incentives. In this study, the City of Palo Alto, Austin Energy, and Seattle City Light are public utilities that are mandated by their states to pursue energy efficiency options; these utilities were also had effective programs, unlike KCBPU. Though some other U.S. public utilities may not have efficiency mandates, they are held directly accountable by their customers and are supposed to provide services to benefit the public, such as energy efficiency programs. To remain competitive in a state with high energy efficiency requirements for investorowned utilities, public utilities should provide similar services to their customers. Also, 
utilities may be more likely to provide efficiency options to customers if energy efficiency is a priority in its state (Hayes et al. 2011).

Energy efficiency programs were the most cost-effective for utilities with larger DSM portfolios. Alabama Power, KCP\&L, and KCBPU had limited program offerings and their programs were not cost-effective. Also, these were the utilities in states without efficiency mandates. If there are no types of targets or incentives in place for these utilities, they will be less likely to make energy efficiency a priority.

\section{Conclusions}

Since the 1970s, some U.S. electric utilities have been investing in energy efficiency programs. Energy efficiency is an important utility and consumer resource to battle rising energy costs. As state governments and utilities recognize the importance of efficiency, utility DSM program portfolios and energy savings will continue to grow. However, there will always be major differences between utility DSM programs throughout the U.S. as long as electricity market structure and energy policies vary by state.

This thesis revealed that there are not major differences in the effectiveness of utility efficiency programs in states that have deregulated their electricity market versus those that have not, and between public and investor-owned utilities. Though this study used a relatively small sample of utilities, the most obvious possible linkage between effective DSM programs and utilities is the energy policies of the state. States that mandate their utilities to have energy efficiency programs and to meet energy savings 
goals typically had the highest energy savings per customer and the most cost-effective programs. Also, large public utilities with a longstanding dedication to energy efficiency, such as Seattle City Light and Austin Energy, had relatively high energy savings results. In addition, City of Palo Alto, the small public utility in California, had higher energy savings per customer than KCBPU, possibly due to California's dedication to energy efficiency and mandates. Overall, utilities in Kansas, Missouri, and Alabama had the lowest energy savings per customer and the least cost-effective programs. This may be because their states also had the fewest to no energy efficiency standards, though more research should be conducted to prove this.

In addition, future research should be done to compare utility energy efficiency programs and programs sponsored by third-party administrators, which are non-profit environmental efficiency companies. An example is Wisconsin's statewide energy efficiency program, Wisconsin's Focus on Energy. As some states are beginning to place these administrators in charge of energy efficiency programs to standardize efforts, the effectiveness of these programs should be investigated. Third-party administrators are being used to coordinate energy efficiency efforts throughout entire states. Therefore, it would be interesting to determine if these programs are more successful than programs offered by individual utility companies.

Overall, energy efficiency programs can be effective if given a high priority by the utility or the state. Multiple DSM programs included in this study were more costeffective than generating one $\mathrm{kWh}$ of electricity. Energy efficiency will continue to grow in importance as the U.S. and world face problems with energy supply and climate 
change. As the U.S. has crucial energy issues to address, state policies concerning energy efficiency are likely to adopt more ambitious targets and higher incentives for utilities; most states have recently increased utility energy efficiency requirements. Though some utility programs are currently much more effective than others, the energy savings from all of these programs are likely to grow in the future as efficiency becomes an important energy resource. 


\section{References}

Adi K, Anders C, Anders SJ. 2006. Following California's Public Goods Charge: Tracking Contributions and Expenditures of the Renewable Energy Program and the PIER Program. Energy Policy Initiatives Center: University of San Diego School of Law.

Alabama Power [Internet]. 2011. Save Money and Energy; [cited 2011 Feb 14]. Available from: http://www.alabamapower.com/residential/energy.asp.

American Council for an Energy-Efficient Economy [Internet]. 2009. The 2009 State Efficiency Scorecard; Report Number E097; [cited 2010 Nov 14]. Available from:

http://www.aceee.org/sites/default/files/publications/researchreports/E097.pdf.

American Council for an Energy-Efficient Economy [Internet]. 2010. State Energy Policy Database; [cited 2011 Feb 22]. Available from: http://www.aceee.org/energyefficiency-sector/state-policy.

American Public Power Association [Internet]. 2011. Energy Efficiency Programs; [cited 2011 Apr 20]. Available from: http://www.publicpower.org/files/PDFs/StateRPSEEupdatesJanuary2011.pdf.

Austin Energy. 2008. 2008 Austin Energy Annual Report. Austin (TX): Distributed Energy Services.

Austin Energy. 2010. DSM Performance Measures: Fiscal Year 2008-2009. Austin (TX): Distributed Energy Services.

Baker-Stariha BD. 1993. Demand Side Management for Natural Gas: Regulation and Implementation. Canadian Energy Research Institute (Calgary, Alta).

Berry D. 2008. The impact of energy efficiency programs on the growth of electricity sales. Energy Policy 36:3620-3625.

Blumstein C, Goldman C, Barbrose G. 2005. Who should administer energy-efficiency programs? Energy Policy. 33:1053-1067.

Brennan TJ, Palmer KL, Martinez SA. 2002. Alternating Currents: Electricity Markets and Public Policy. Washington, DC: Resources for the Future.

Byrne J, Hughes K, Rickerson W, Kurdgelashvili L. 2007. American policy conflict in the greenhouse: Divergent trends in federal, regional, state, and local green energy and climate change policy. Energy Policy. 35(9):4555-4573. 
California Municipal Utilities Association [Internet]. 2010. Energy Efficiency in California's Public Power Sector: A Status Report; [cited 2011 Feb 11]. Available from: http://cleanefficientenergy.org/resource/energy-efficienycalifornias-public-power-sector-status-report.

Curtis M, Khare A. 2004. Energy conservation in electric utilities: an opportunity for restorative economics at SaskPower. Technovation. 24:395-402.

Connecticut Light and Power Company and United Illuminating Company [Internet]. 2010a. UI and CL\&P Program Savings Documentation for 2011 Program Year; [cited 2011 Jan 18]. Available from:

http://neep.org/uploads/EMV\%20Forum/EMV\%20Studies/FINAL\%202011\%20 CT\%20PSD.pdf.

Connecticut Light and Power Company, United Illuminating Company, Yankee Gas Services Company, Connecticut Natural Gas Corporation, and Southern Connecticut Gas Company. 2010b. Electric and Natural Gas Conservation and Load Management Plan. CT Docket 10-10-03, 10-10-04.

CT Energy Info Center [Internet]. 2011. Combined Public Benefits Charge; [cited 2011 Feb 27]. Available from: http://www.ctenergyinfo.com/dpuc_combined_public_benefits_charge.htm.

Database of State Incentives for Renewables and Efficiency [Internet]. 2010a. Ohio Incentives/Policies for Energy Efficiency; [cited 27 Feb. 2011]. Available from: http://www.dsireusa.org/incentives/incentive.cfm?Incentive_Code $=\mathrm{OH} 16 \mathrm{R} \& \mathrm{re}=0$ \&ee $=1$.

Database of State Incentives for Renewables and Efficiency [Internet]. 2010b. Systems Benefits Charge; [cited 2010 Sept 26]. Available from:

http://www.dsireusa.org/incentives/incentive.cfm?Incentive_Code=NY07R\&state $=\mathrm{NY} \&$ CurrentPageID $=1 \& \mathrm{RE}=1 \& \mathrm{EE}=1$.

Duke Energy [Internet]. 2010. 2009-2010 Sustainability Report; [cited 2011 Jan 20]. Available from: http://sustainabilityreport.dukeenergy.com/downloads/downloads-home.asp.

Energy Information Administration [Internet]. 2010a. Form EIA-861 Final Data File for 2009; [cited 2011 Feb 2]. Available from: http://www.eia.doe.gov/cneaf/electricity/page/eia861.html.

Energy Information Administration [Internet]. 2010b. Status of Restructuring by State; [cited 2010 Sept. 24]. Available from: http://www.eia.doe.gov/cneaf/electricity/page/restructuring/restructure_elect.html. 
Eto J. 1996. The Past, Present, and Future of U.S. Utility Demand-Side Management Programs. Environmental Energy Technologies Division, Ernest Orlando Lawrence Berkeley National Laboratory.

Federal Energy Regulatory Commission. 2006. Report to Congress on Competition in Wholesale and Retail Markets for Electric Energy. The Electric Energy Market Competition Task Force. Washington, DC.

Flanigan T, Weintraub J. 1993. The most successful DSM programs in North America. The Electricity Journal. 6(4):53-65.

Florida Public Service Commission [Internet]. 2006. Annual Report on the Florida Energy and Conservation Act; [cited 2011 Feb 27]. Available from: http://www.psc.state.fl.us/publications/pdf/electricgas/FEECA2006.pdf.

Florida Public Service Commission. 2008. Annual Report on Activities Pursuant to the Florida Energy Efficiency and Conservation Act. Florida Public Service Commission, Division of Economic Regulation.

Florida Public Service Commission [Internet]. 2011. Florida Investor-Owned Utilities' Demand-Side Management Achievements Comparative Analysis; [cited 2011 Jan 25]. Available from:

http://www.psc.state.fl.us/publications/pdf/electricgas/DSM_Peer_Report_201_01 _20_final.pdf.

Geller H. 2004. Utility Energy Efficiency Policies and Programs in the Southwest. Southwest Energy Efficiency Project.

Hall N [Internet]. 2008. Evaluation Issues Facing State Regulatory Offices. Kansas Corporation Commission: Energy Efficiency Workshop (presentation); [cited 2011 Feb 4]. Available from: http://www.kcc.state.ks.us/energy_efficiency/hall.ppt.

Hayes S, Nadel S, Kushler M, York D [Internet]. 2011. Carrots for Utilities: Providing Financial Returns for Utility Investments in Energy Efficiency. American Council for an Energy-Efficient Economy; [cited 2011 Mar 19]. Available from: http://www.aceee.org/research-report/u111.

Heinberg R. 2003. The Party's Over: Oil, War, and the Fate of Industrial Societies. Gabriola Island (Canada): New Society Publishers.

Hirst E, Cavanaugh R, Miller P. 1996. The future of DSM in a restructured US electricity industry. Energy Policy. 24(4):303-315. 
Indiana Utility Regulatory Commission [Internet]. 2010a. Demand-side Management Programs; [cited 2011 Feb 27]. Available from: http://www.in.gov/iurc/2571.htm.

Indiana Utility Regulatory Commission. 2010b. Submittal of Duke Energy Indiana Inc.'s Energy Efficiency Program Annual Report for 2009. Cause No. 42612.

Institute for Electric Efficiency [Internet]. 2010. Implementing Energy Efficiency: Program Delivery Comparison Study; [cited 2011 Feb 14]. Available from: www.electricefficiency.com/reports/IEE_EEProgDeliveryComparison.pdf.

Institute for Energy Research [Internet]. 2010. Alabama Energy facts; [cited2011 Feb. 27]. Available from: http://www.instituteforenergyresearch.org/stateregs/pdf/Alabama.pdf.

Kansas City Board of Public Utilities [Internet]. 2010. Energy Efficiency Programs for your Home; [cited 2011 Feb 14]. Available from: http://www.bpu.com/customer_service/energy_eff_residential.jsp.

Kansas Corporation Commission. 2011. Errata to Kansas City Power \& Light Company Direct Testimony Correcting Certain Confidential Testimony Designations. Docket No. 10-KCPE-795-TAR.

Lantz E. 2010. State Clean Energy Policies Analysis: State, Utility, and Municipal Loan Programs. National Renewable Energy Laboratory. Technical Report: NREL/TP-6A2-47376.

Menz F. 2005. Green electricity policies in the U.S.: case study. Energy Policy. 33(18):2398-2410.

Missouri Public Service Commission [Internet]. 2009. Missouri Energy Efficiency Act: SB 376; [cited $2011 \mathrm{Feb} 27$ ]. Available from: http://www.senate.mo.gov/09info/BTS_Web/Bill.aspx?SessionType=R\&BillID= 834581 .

M.J. Bradley \& Associates, LLC [Internet]. 2009. State and Utility Administered Energy Efficiency Programs: Experience, Opportunities and Examples; [cited 2010 Nov 14]. Available from: http://www.stellacolor.com/downloads/energy.pdf.

Northwest Power and Conservation Council [Internet]. 2010. About Us; [cited 2011 Feb 22]. Available from: http://www.nwcouncil.org/about/. 
Nuclear Energy Institute [Internet]. 2010. U.S. Electricity Production Costs and Components: 1995-2009; [cited 2011 Apr 21]. Available from:

http://www.nei.org/resourcesandstats/documentlibrary/reliableandaffordableenerg y/graphicsandcharts/uselectricityproductioncostsandcomponents/.

Ohio Department of Development [Internet]. 2007. Energy efficiency revolving loan program: 4928.62; [cited $2011 \mathrm{Feb} 27$ ]. Available from: http://codes.ohio.gov/orc/4928.62.

Pacific Gas and Electric Company. 2010. Energy Efficiency Program Portfolio Annual Report for 2009.

Palmer K, Burtraw D. 2005. The Environmental Impacts of Electricity Restructuring: Looking Back and Looking Forward. Resources for the Future Discussion Paper 05-07.

Public Utility Commission of Texas [Internet]. 2010. Energy Efficiency Goal: 25.18. [cited $2011 \mathrm{Feb} 27]$. Available from: http://www.puc.state.tx.us/rules/subrules/electric/25.181/25.181.pdf.

Seattle City Light. 2008. 2008-2012 Action Plan. Conservation Resources Division of Seattle City Light.

Seattle City Light [Internet]. 2009. A Test of Our Resilience: 2009 Annual Report; [cited $2010 \mathrm{Jul}$ 27]. Available from: http://www.seattle.gov/light/AboutUs/AnnualReport/2009/2009AnnualReport.pdf

Sharabaroff A, Boyd R, Chimeli A. 2009. The environmental and efficiency effects of restructuring on the electric power sector in the United States: An empirical analysis. Energy Policy. 37:4884-4893.

Sioshansi FP. 2001. US electricity restructuring experience: hits and misses. Utilities Policy. 10:1-6.

State of Connecticut [Internet]. 2007. HB-7432: An Act Concerning Electricity and Energy Efficiency; [cited $2011 \mathrm{Feb} 27$ ]. Available from: http://www.cga.ct.gov/2007/ba/2007HB-07432-R01-BA.htm.

State of Washington [Internet]. 2006. Initiative 937; [cited 2011 Feb 27]. Available from: http://www.secstate.wa.gov/elections/initiatives/text/i937.pdf.

Tonn B, Peretz JH. 2007. State level benefits of energy efficiency. Energy Policy. 35:3665-3674. 
U.S. Congress, Office of Technology Assessment. 1993. Energy Efficiency: Challenges and Opportunities for Electric Utilities, OTA-E-561. Washington, DC: U.S. Government Printing Office.

United States Department of Energy [Internet]. 2008. Appliances and Commercial Equipment Standards; [cited 2011 Feb 27]. Available from:

http://www1.eere.energy.gov/buildings/appliance_standards/history.html.

United States Department of Energy [Internet]. 2009. National Energy Conservation Policy Act: Laws and Regulations; [cited 14 Sept. 2010]. Available from: http://www1.eere.energy.gov/femp/regulations/necpa.html.

Vine E, Rhee CH, Lee, KH. 2006. Measurement and evaluation of energy efficiency programs: California and South Korea. Energy. 31:1100-1113.

Wilson EJ, Plummer J, Fischlein M, Smith TM. 2008. Implementing energy efficiency: Challenges and opportunities for rural electric co-operatives and small municipal utilities. Energy Policy. 36:3383-3397. 